\title{
Article \\ Serotonergic-Muscarinic Interaction within the Prefrontal Cortex as a Novel Target to Reverse Schizophrenia-Related Cognitive Symptoms
}

\author{
Paulina Cieślik 1,*D , Adrianna Radulska ${ }^{2,3}$, Grzegorz Burnat ${ }^{1}$ (D), Leszek Kalinowski ${ }^{2,3,4}$ \\ and Joanna M. Wierońska ${ }^{2, *}$ \\ 1 Department of Neurobiology, Maj Institute of Pharmacology, Polish Academy of Sciences, \\ 12 Smętna Street, 31-343 Kraków, Poland; burnat@if-pan.krakow.pl \\ 2 Department of Medical Laboratory Diagnostics—Fahrenheit Biobank BBMRI.pl, \\ Medical University of Gdańsk, 7 Dębinki Street, 80-211 Gdańsk, Poland; \\ adrianna.radulska@gumed.edu.pl (A.R.); leszek.kalinowski@gumed.edu.pl (L.K.) \\ 3 Biobanking and Biomolecular Resources Research Infrastructure Consortium Poland (BBMRI.pl), \\ 7 Dębinki Street, 80-211 Gdańsk, Poland \\ 4 BioTechMed Centre, Department of Mechanics of Materials and Structures, University of Technology, \\ 11/12 Narutowicza Street, 80-223 Gdańsk, Poland \\ * Correspondence: cieslik@if-pan.krakow.pl (P.C.); wierons@if-pan.krakow.pl (J.M.W.); \\ Tel.: +48-126-623-292 (P.C.); +48-126-623-288 (J.M.W.)
}

\section{check for} updates

Citation: Cieślik, P.; Radulska, A.; Burnat, G.; Kalinowski, L.; Wierońska, J.M. Serotonergic-Muscarinic Interaction within the Prefrontal Cortex as a Novel Target to Reverse Schizophrenia-Related Cognitive Symptoms. Int. J. Mol. Sci. 2021, 22, 8612. https://doi.org/10.3390/ijms 22168612

Academic Editor:

Juan F. Lopez-Gimenez

Received: 28 June 2021

Accepted: 5 August 2021

Published: 10 August 2021

Publisher's Note: MDPI stays neutra with regard to jurisdictional claims in published maps and institutional affiliations.

Copyright: (c) 2021 by the authors. Licensee MDPI, Basel, Switzerland. This article is an open access article distributed under the terms and conditions of the Creative Commons Attribution (CC BY) license (https:// creativecommons.org/licenses/by/ $4.0 /$ )

\begin{abstract}
Recent studies revealed that the activation of serotonergic $5-\mathrm{HT}_{1 \mathrm{~A}}$ and muscarinic $\mathrm{M}_{1}$, $\mathrm{M}_{4}$, or $\mathrm{M}_{5}$ receptors prevent $\mathrm{MK}-801$-induced cognitive impairments in animal models. In the present study, the effectiveness of the simultaneous activation of $5-\mathrm{HT}_{1 \mathrm{~A}}$ and muscarinic receptors at preventing MK-801-induced cognitive deficits in novel object recognition (NOR) or Y-maze tests was investigated. Activators of 5- $\mathrm{HT}_{1 \mathrm{~A}}$ (F15599), $\mathrm{M}_{1}$ (VU0357017), $\mathrm{M}_{4}$ (VU0152100), or $\mathrm{M}_{5}$ (VU0238429) receptors administered at top doses for seven days reversed MK-801-induced deficits in the NOR test, similar to the simultaneous administration of subeffective doses of F15599 $(0.05 \mathrm{mg} / \mathrm{kg})$ with VU0357017 (0.15 mg/kg), VU0152100 (0.05 mg/kg), or VU0238429 (1 mg/kg). The compounds did not prevent the MK-801-induced impairment when administered acutely. Their activity was less evident in the Y-maze. Pharmacokinetic studies revealed high brain penetration of F15599 (brain/plasma ratio $620 \%$ ), which was detected in the frontal cortex (FC) up to $2 \mathrm{~h}$ after administration. Decreases in the brain penetration properties of the compounds were observed after acute administration of the combinations, which might have influenced behavioral responses. This negative effect on brain penetration was not observed when the compounds were administered repeatedly. Based on our results, prolonged administration of a $5-\mathrm{HT}_{1 \mathrm{~A}}$ activator with muscarinic receptor ligands may be effective at reversing cognitive decline related to schizophrenia, and the FC may play a critical role in this interaction.
\end{abstract}

Keywords: schizophrenia; cognitive deficits; muscarinic receptors; $\mathrm{M}_{1} ; \mathrm{M}_{4} ; \mathrm{M}_{5} ; 5-\mathrm{HT}_{1 \mathrm{~A}}$

\section{Introduction}

Cognitive disturbances accompany the majority of mental and neurodegenerative disorders, including schizophrenia. Deficits may appear premorbidly in children and adolescents or occur suddenly; they persist chronically and may worsen over time, affecting daily functioning [1-3]. Multiple cognitive domains are affected in patients with schizophrenia [1,4], and up to date remain treatment resistant, although cognitive deficits in some individuals may be ameliorated with atypical antipsychotics such as clozapine, olanzapine, or lurasidone [5]. In preclinical experiments with the use of rodent models of learning and memory (e.g., novel object recognition test-NOR) the administration of atypical neuroleptics reversed cognitive decline induced by the administration of open 
channel blockers (OCB) of NMDA receptor, such as MK-801 (also known as dizocilpine) or phencyclidine (PCP) [6-9]. Putatively, activation of the $5-\mathrm{HT}_{1 \mathrm{~A}}$ receptor by atypical neuroleptics is responsible for their efficacy in reversing cognitive symptoms associated with schizophrenia [10,11].

Based on these observations, the modulation of $5-\mathrm{HT}_{1 \mathrm{~A}}$ receptors alone or as an add-on therapy might be beneficial in treating cognitive deficits in patients with schizophrenia [12]. As shown in our earlier studies, the activation of $5-\mathrm{HT}_{1 \mathrm{~A}}$ receptors plays an essential role in the procognitive activity of activators of group II or III metabotropic glutamatergic receptors, such as LY487379 or LSP4-2022. Their activity was inhibited by the administration of WAY100635 (5- $\mathrm{HT}_{1 \mathrm{~A}}$ antagonist) or enhanced by the administration of (R,S)-8-OH-DPAT (5- $\mathrm{HT}_{1 \mathrm{~A}}$ agonist) [7,13-15].

Both WAY100635 and (R,S)-8-OH-DPAT act in a two-phase manner. Low doses of the compounds are presumed to act at the presynaptic $5-\mathrm{HT}_{1 \mathrm{~A}}$ receptors localized in the raphe, while higher doses act at both the presynaptic and postsynaptic sites. Activation of postsynaptic receptors by high doses of agonists (R,S)-8-OH-DPAT may result in the development of serotonergic syndrome (lower lip retraction, forepaw treading, and flat body posture) $[16,17]$ and constitute the limitation of their use, especially since they disturb memory processes [18]. Therefore, the use of selective biased agonists might be a better option. The recently developed compound F15599 (also known as NLX-101) preferentially stimulates postsynaptic 5- $\mathrm{HT}_{1 \mathrm{~A}}$ receptors in brain structures related to learning and memory processes, such as the frontal cortex and septo-hippocampal neurons, instead of dorsal raphe neurons $[19,20]$.

In our previous studies, selected muscarinic ligands (VU0357017- $\mathrm{M}_{1}$ allosteric agonist, VU0152100- $\mathrm{M}_{4}$ positive allosteric modulator (PAM), and VU0238429- $\mathrm{M}_{5} \mathrm{PAM}$ ) ameliorated MK-801-induced deficits in tests assessing cognition, such as the NOR test or prepulse inhibition [21-23]. The action of the compounds was shown to be enhanced with the administration of metabotropic glutamatergic ( $\mathrm{mGlu}$ ) or $\mathrm{GABA}_{B}$ receptor activators [21-24].

To date, no data are available concerning the interaction between muscarinic and $5-\mathrm{HT}_{1 \mathrm{~A}}$ receptors, which is potentially interesting because of their overlapping expression in the structures involved in learning and memory processes. In the present study, the effectiveness of the simultaneous administration of muscarinic ligands (VU0357017, VU0152100, and VU0238429) with a biased agonist of 5- $\mathrm{HT}_{1 \mathrm{~A}}$ receptors (F15599) (the chemical structures of the compounds are presented on Figure 1) at reversing schizophrenia-related cognitive disturbances was examined in behavioral tests assessing memory processes (NOR test and Y-maze). The potential of the combinations to prevent or reverse MK-801-induced deficits was examined after acute or chronic administration of the tested compounds. Pharmacokinetic studies were performed to exclude any potential drug-drug interactions influencing the brain penetration properties of the compounds. The analysis was performed in the frontal cortex both after the administration of the drugs alone at the top doses and combinations at subeffective doses based on behavioral studies. The compounds were administered either acutely or repeatedly. 
<smiles>Cc1cnc(CNCC2(F)CCN(C(=O)c3ccc(F)c(Cl)c3)CC2)nc1</smiles>

VU0152100

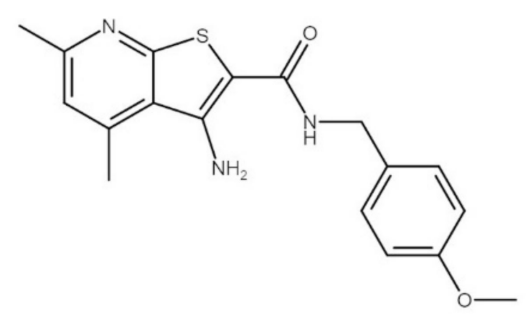<smiles>CCOC(=O)N1CCC(NCCNC(=O)c2ccccc2C)CC1</smiles>

VU0238429

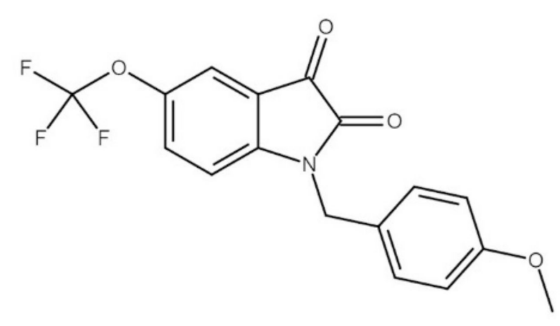

Figure 1. Chemical structure of F15599, VU0357017, VU0152100, and VU0238429.

\section{Results}

\subsection{Treatment Regimen}

Drugs were administered on two different schedules: (1) acute administration of compounds $45 \mathrm{~min}$ (WAY100635-5- $\mathrm{HT}_{1 \mathrm{~A}}$ antagonist) or $30 \mathrm{~min}$ (VU0357017, VU152100, VU0238429, and F15599) before MK-801 (also administered once 30 min before the test in Ymaze or $\mathrm{T}_{1}$ in NOR test); and (2) prolonged administration (once per day for 7 consecutive days) of the compounds and MK-801 with the last administration $24 \mathrm{~h}$ before the test (NOR test) or at the day of the test (Y-maze). This difference was due to the lack of MK-801 disruptive effect on animals' behavior in Y-maze when the test was performed $24 \mathrm{~h}$ after the last administration. Schedules of administration are presented graphically in Figure 2. The subeffective doses of the compounds for acute administration in the NOR test were chosen based on our previous research (see: [22,23]) while dose-dependent studies of the activity of the compounds in reversing disruptions in the Y-maze or after prolonged administration along with MK-801 were performed within this study. Different vehicles were used throughout the study: (1) $0.9 \% \mathrm{NaCl}$ and (2) $10 \%$ Tween 80 . Vehicles were administered to all animals (e.g., control mice and MK-801-treated mice) on the same schedule as drugs were administered to the appropriate drug-treated groups of mice. Neither solvent exerted effects on animal behavior.

\subsection{Acute Administration}

\subsubsection{Activity of F15599 in NOR and Y-Maze Test}

MK-801 induced typical disruption in the recognition index (at least $p<0.01$ ) and spontaneous alternations in the Y-maze $(p<0.05)$.

The administration of F15599 at 0.1 or $0.5 \mathrm{mg} / \mathrm{kg}$ reversed the MK-801-induced deficits in the NOR test $\left(\mathrm{F}_{(3,30)}=14.79, p<0.001\right.$ ) (Figure 3A). The dose of $0.05 \mathrm{mg} / \mathrm{kg}$ was ineffective. F15599 administered at doses of $0.05-0.5 \mathrm{mg} / \mathrm{kg}$ showed no efficacy in the Y-maze test (Figure 3B). 
A

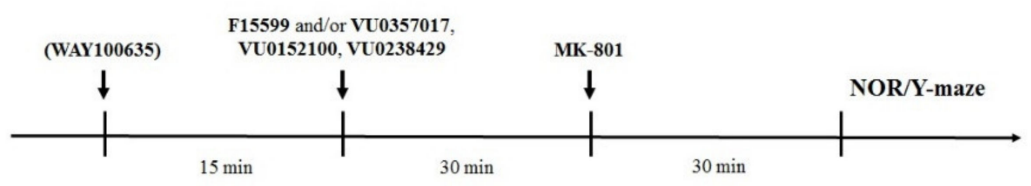

B

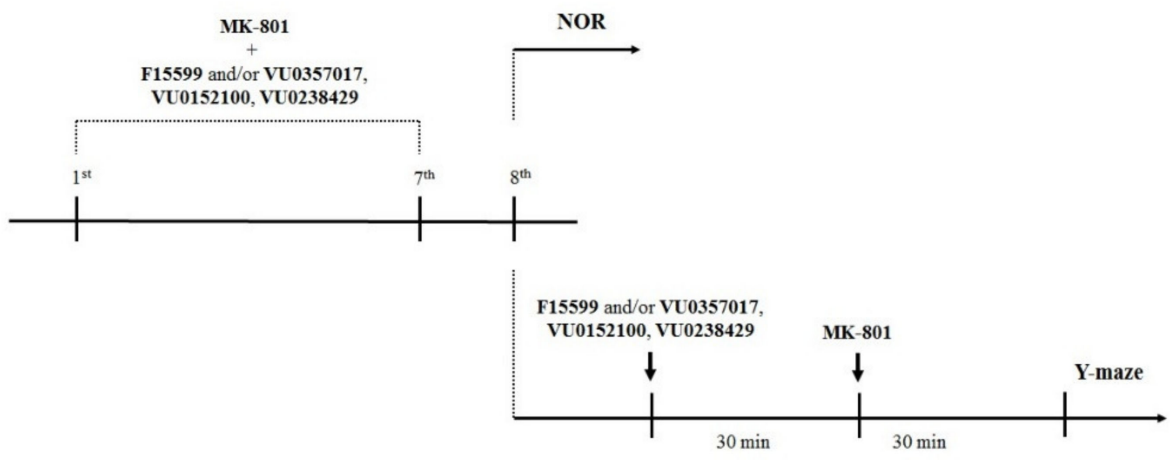

Figure 2. Schematic representation of the experiments performed in this study. (A) Acute administration of the investigated compounds and MK-801. (B) Prolonged administration of the investigated compounds and MK-801.

A

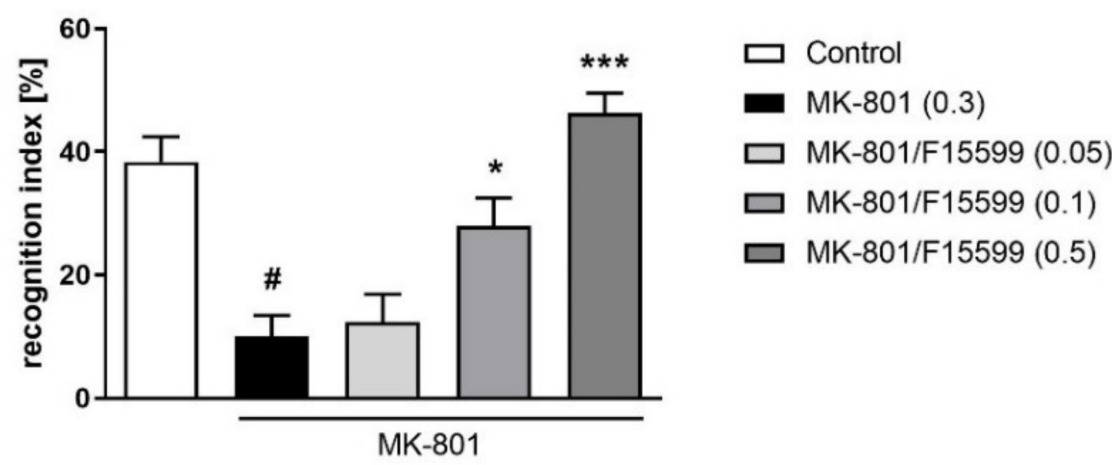

B

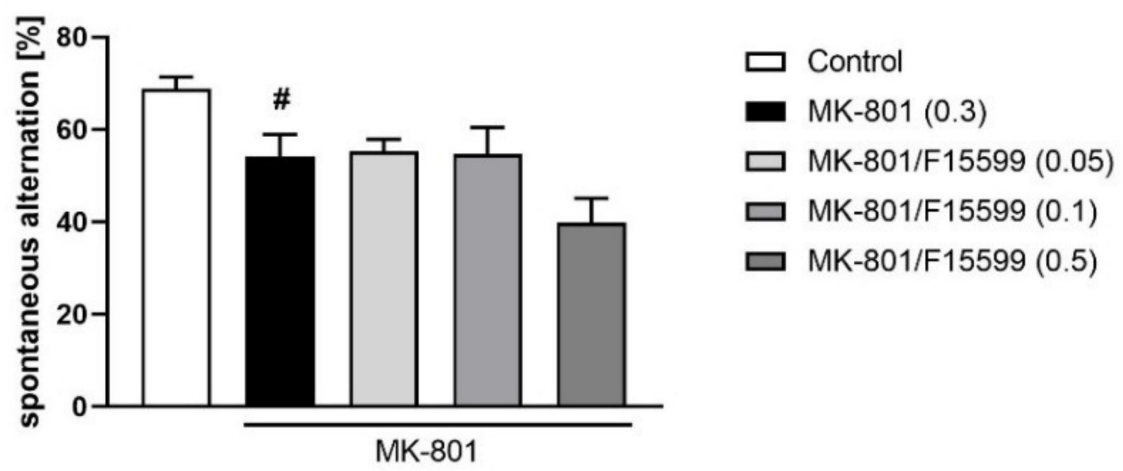

Figure 3. Activity of F15599 in the NOR (A) or Y-maze (B) test. The data are presented as means \pm SEM. Doses of the compounds are indicated in parentheses. \# $p<0.001$ (A) or \# $p<0.01$ (B) compared to control animals and ${ }^{*} p<0.05$, ${ }^{* * *} p<0.001$ compared to MK-801-treated mice. 


\subsubsection{Activity of Muscarinic Activators in the Y-Maze Test}

No efficacy was observed for VU0357017 administered at doses of $1-10 \mathrm{mg} / \mathrm{kg}$ or VU0152100 administered at doses of $0.1-5 \mathrm{mg} / \mathrm{kg}$. VU0238429 reversed the reduction in spontaneous alternations in the Y-maze induced by MK-801 $\left(\mathrm{F}_{(3,34)}=3.372, p<0.05\right)$ at doses of 10 and $20 \mathrm{mg} / \mathrm{kg}$. The dose of $5 \mathrm{mg} / \mathrm{kg}$ was ineffective (Figure 4).

A
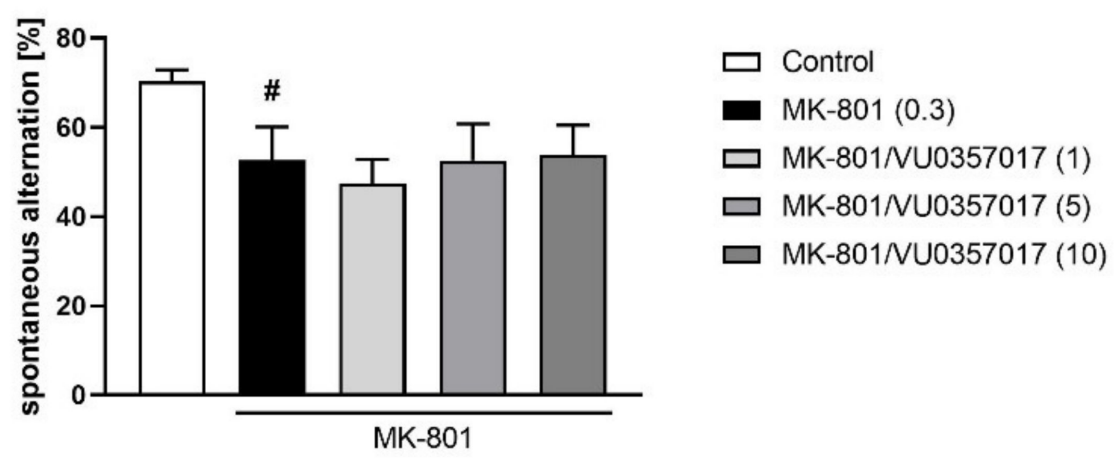

B
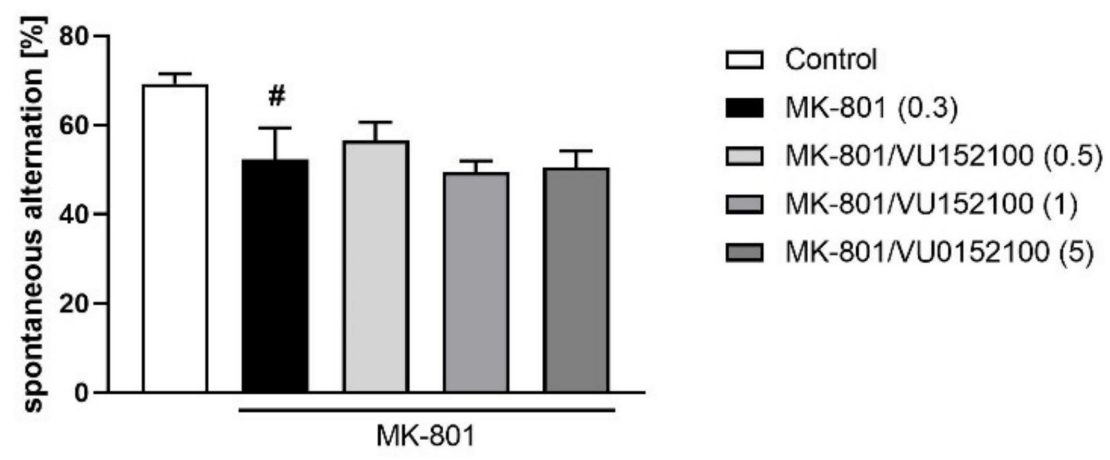

C

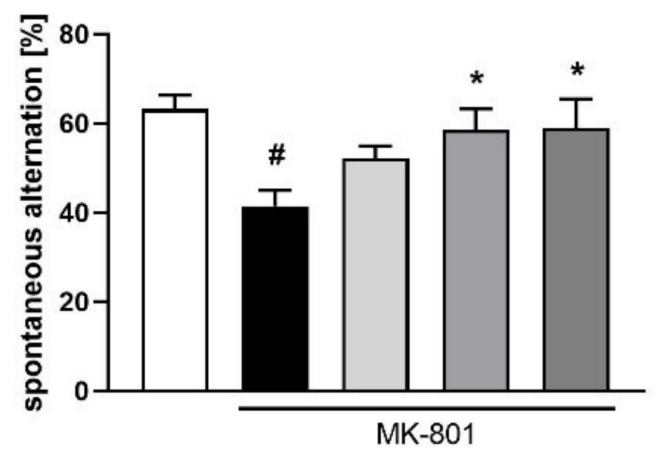

$$
\begin{aligned}
& \square \text { Control } \\
& \text { MK-801 (0.3) } \\
& \square \text { MK-801/NU0238429(5) } \\
& \square \text { MK-801/NU0238429(10) } \\
& \square \text { MK-801/NU0238429(20) }
\end{aligned}
$$

Figure 4. Activity of VU0357017 (A), VU0152100 (B), and VU0238429 (C) in the Y-maze test. The data are presented as means \pm SEM. Doses of the compounds are indicated in parentheses. \# $p<0.05$ (A,B) or \# $p<0.001$ (C) compared to control animals and * $p<0.05$ compared to MK-801-treated mice. 


\subsubsection{Combined Administration of Muscarinic Activators and WAY100635 in NOR Test}

The administration of WAY 100635 at a dose of $0.1 \mathrm{mg} / \mathrm{kg} 15 \mathrm{~min}$ before VU0357017 (5 mg/kg), VU0152100 (1 mg/ $\mathrm{kg})$, or VU0238429 (5 mg/kg) reversed the pro-cognitive effect of the administration of the top doses of the ligands $\left(\mathrm{F}_{(1,29)}=33.8087, p<0.001\right.$; $\mathrm{F}_{(1,33)}=10.7161, p<0.01 ; \mathrm{F}_{(1,25)}=23.7360, p<0.001$, respectively) (Figure 5).

A

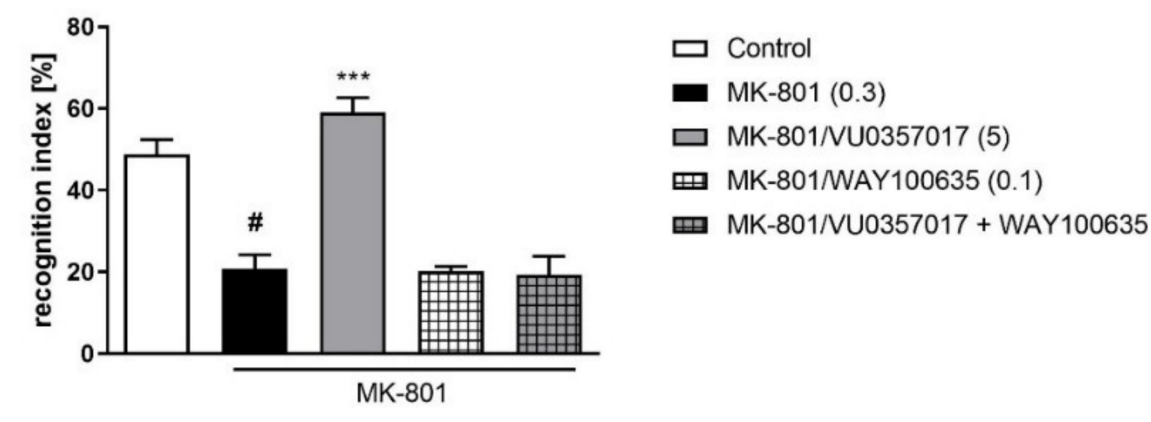

B

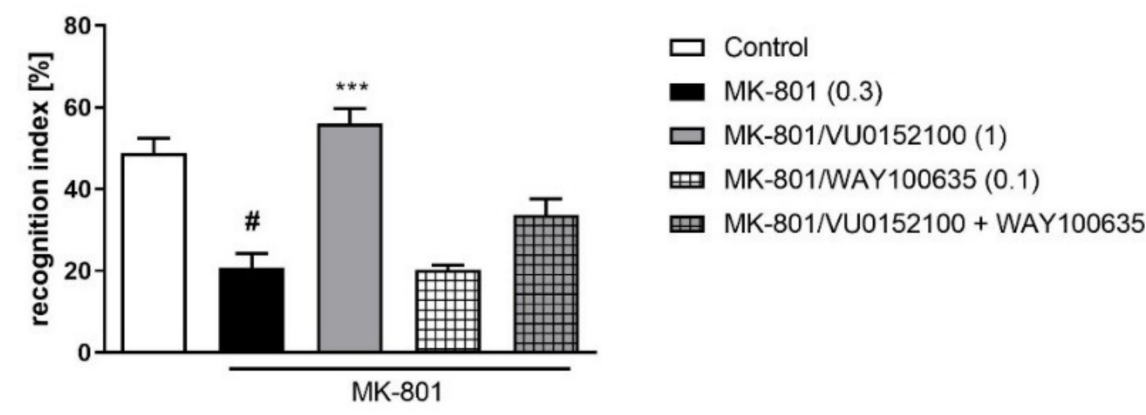

C

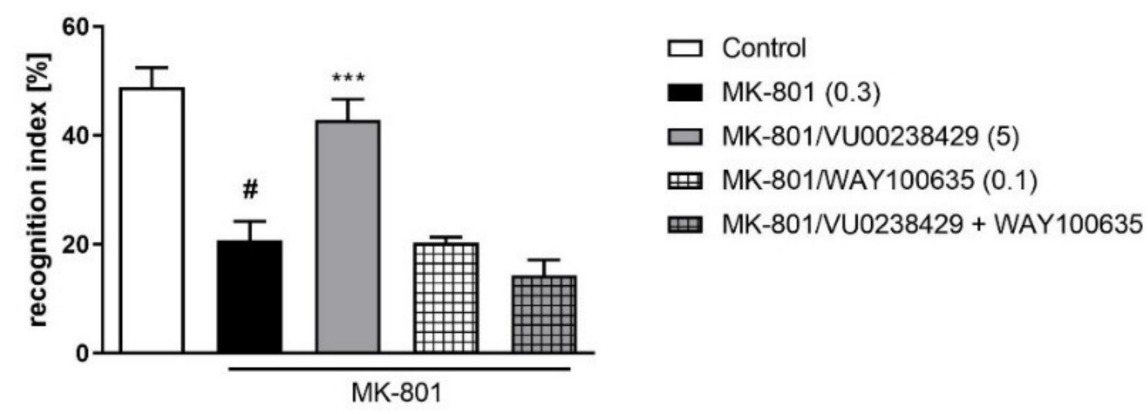

Figure 5. Activity of the combined administration of WAY100635 with active dose of VU0357017 (A), VU0152100 (B), or VU0238429 (C) in the NOR test. The data are presented as means \pm SEM. Doses of the compounds are indicated in parentheses. $\# p<0.001$ compared to control animals and ${ }_{* * *} p<0.001$ compared to MK-801-treated mice.

2.2.4. Combined Administration of Muscarinic Activators and F15599 at Subeffective Doses in NOR and Y-Maze Test

Combined administration of subeffective doses of F15599 with VU0357017, VU0152100, or VU0238429 had no effect on memory deficits induced by MK-801 administration in the NOR test (Figure 6). 
Combined administration of F15599 at a dose of $0.1 \mathrm{mg} / \mathrm{kg}$ together with VU0357017 (10 mg/kg), VU0152100 (1 mg/kg), or VU0238429 (5 mg/kg) had no effect on spontaneous alternations in the Y-maze test (Figure 7).

A

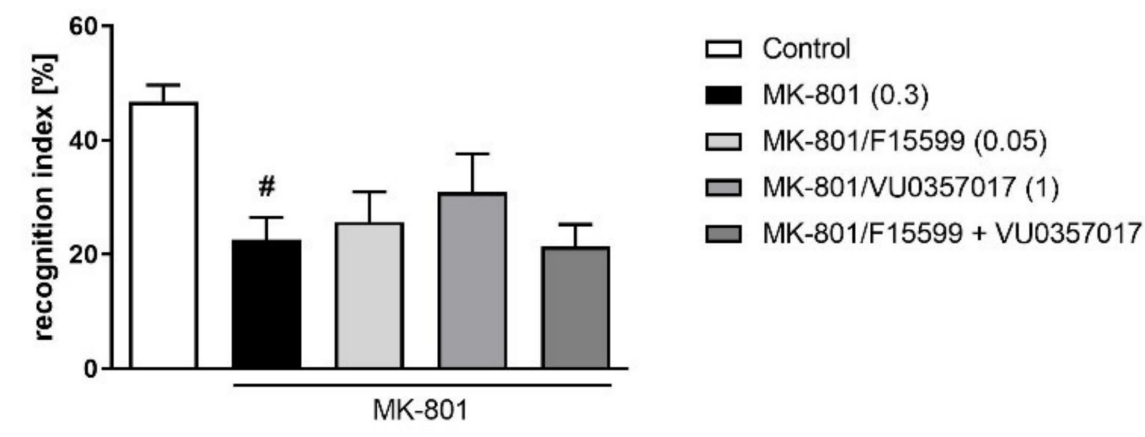

B

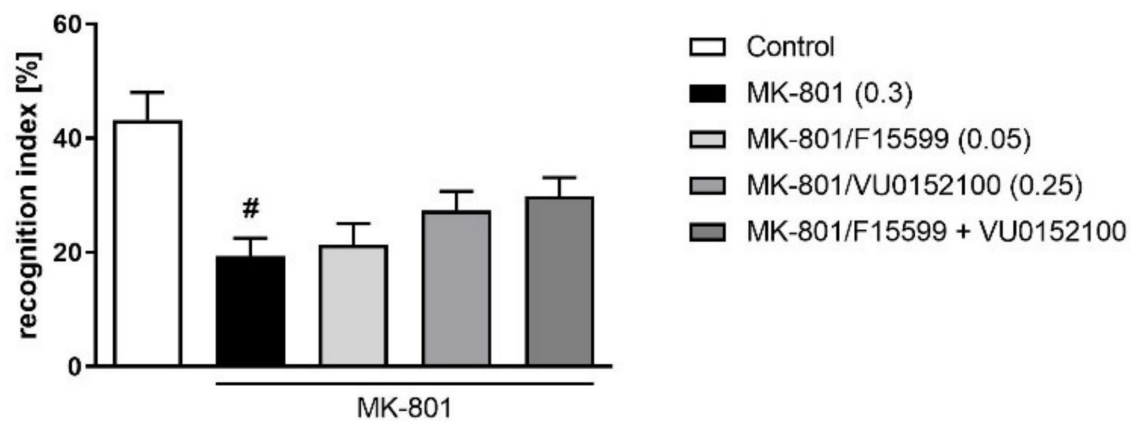

C

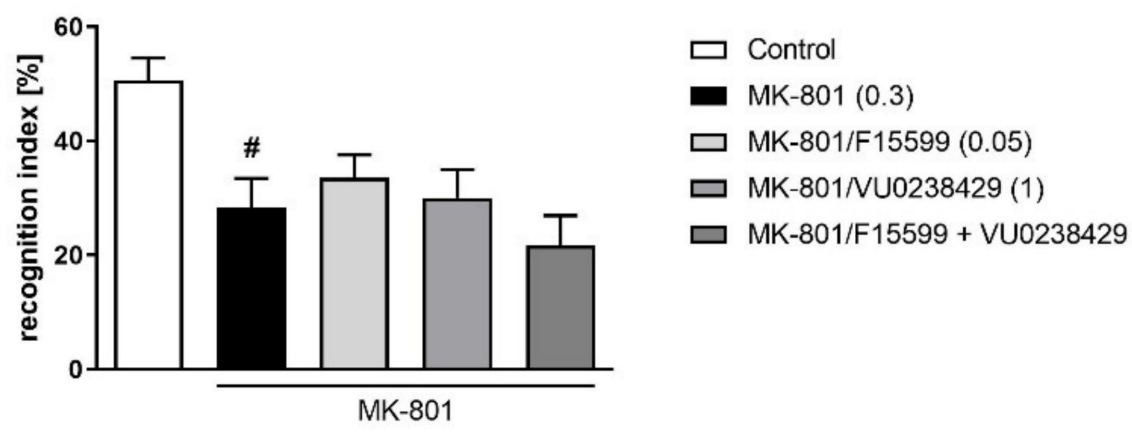

Figure 6. Activity of the combined administration of subeffective dose of F15599 with subeffective dose of VU0357017 (A), VU0152100 (B), or VU0238429 (C) in the NOR test. The data are presented as means \pm SEM. Doses of the compounds are indicated in parentheses. $\# p<0.001(\mathbf{A}, \mathbf{B})$ or $\# p<0.01$ (C) compared to control animals. 


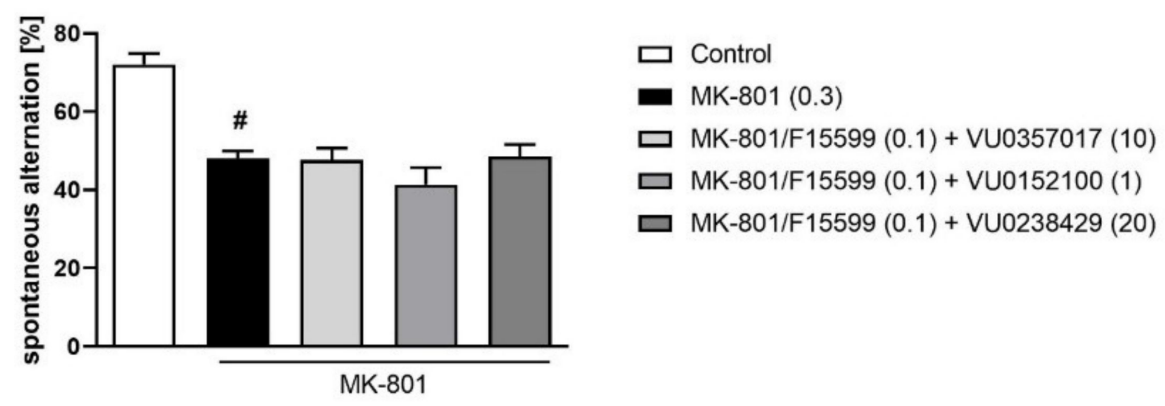

Figure 7. Activity of the combined administration of subeffective dose of F15599 with subeffective dose of VU0357017, VU0152100, or VU0238429 in the Y-maze test. The data are presented as means \pm SEM. Doses of the compounds are indicated in parentheses. \# $p<0.001$ compared to control animals.

\subsection{Chronic Administration}

\subsubsection{Activity of F15599}

Seven days of MK-801 administration induced a typical disruption in the recognition index (at least $p<0.01$ ).

The administration of F15599 at a dose of $0.1 \mathrm{mg} / \mathrm{kg}$ reversed the reduction in the recognition index induced by MK-801 $\left(\mathrm{F}_{(2,34)}=11.21, p<0.001\right)$. The dose of $0.025 \mathrm{mg} / \mathrm{kg}$ was ineffective (Figure 8A).

A
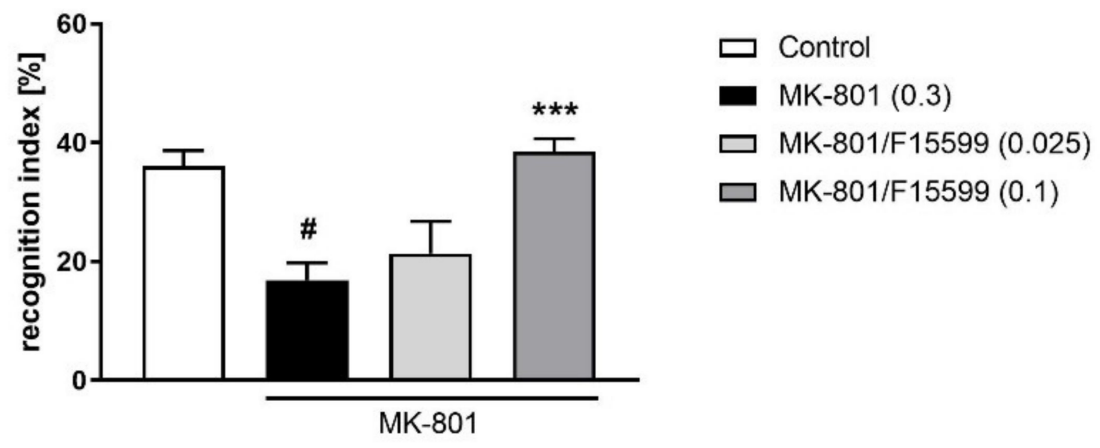

B

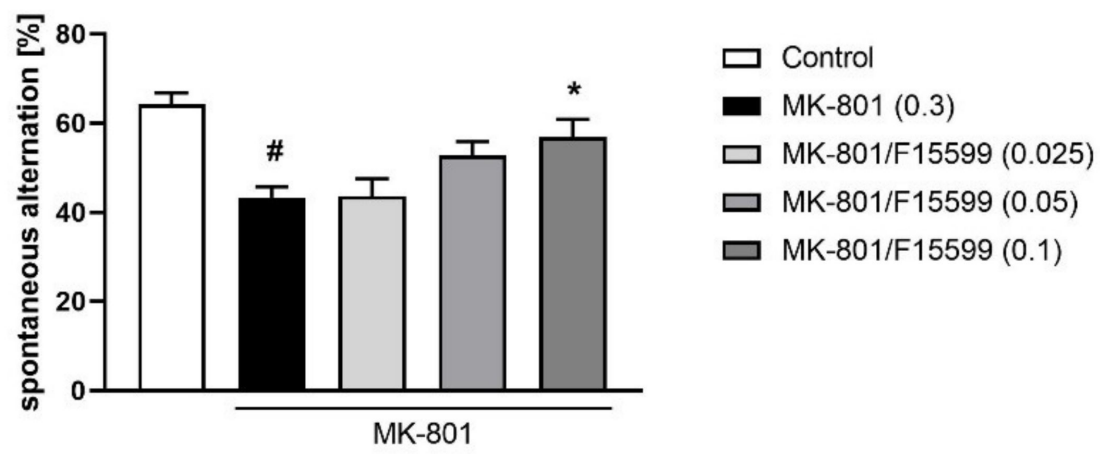

Figure 8. Activity of F15599 in the NOR (A) or Y-maze (B) test after seven days of treatment. The data are presented as means \pm SEM. Doses of the compounds are indicated in parentheses. $\# p<0.001$ compared to control animals and ${ }^{*} p<0.05,{ }^{* * *} p<0.001$ compared to MK-801-treated mice. 
At the highest dose tested $(0.1 \mathrm{mg} / \mathrm{kg}), \mathrm{F} 15599$ reversed the reduction in spontaneous alternations induced by MK-801 $\left(\mathrm{F}_{(3,36)}=4.187 ; p<0.05\right)$ (Figure $\left.8 \mathrm{~B}\right)$. The doses of 0.025 and $0.05 \mathrm{mg} / \mathrm{kg}$ were ineffective.

\subsubsection{Dose-Dependent Activity of Muscarinic Activators}

VU0357017 administered at doses ranging from 0.15 to $5 \mathrm{mg} / \mathrm{kg}$ ameliorated MK801 -induced deficits in the NOR test $\left(\mathrm{F}_{(3,35)}=6.829 ; p<0.001\right)$. The dose of $0.15 \mathrm{mg} / \mathrm{kg}$ was ineffective. The activity of VU0152100 was observed at doses of 0.1 and $1 \mathrm{mg} / \mathrm{kg}$ $\left(\mathrm{F}_{(3,35)}=17.38 ; p<0.001\right)$, and a dose of 0.05 was ineffective. VU0238429 was only active at a dose of $5 \mathrm{mg} / \mathrm{kg}\left(\mathrm{F}_{(3,35)}=8,067 ; p<0.001\right)$, and doses of 0.5 and $1 \mathrm{mg} / \mathrm{kg}$ were ineffective (Figure 9).

\section{A}

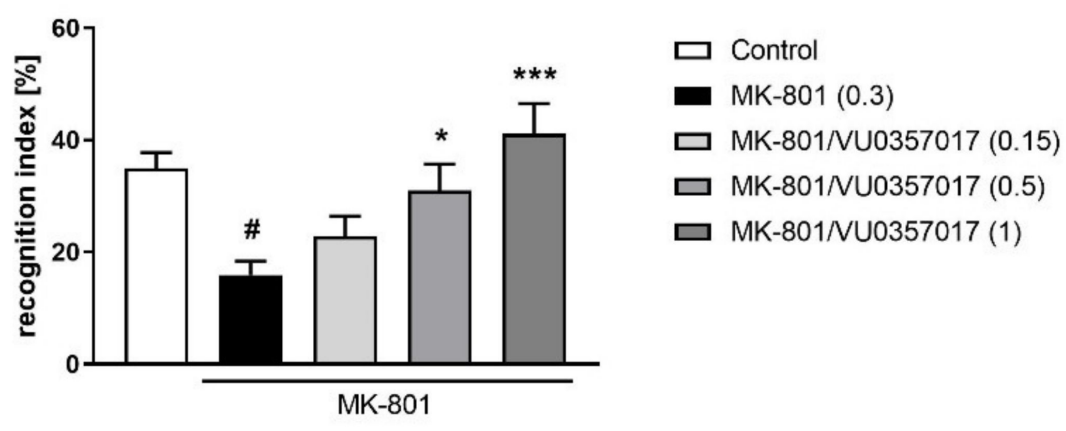

B

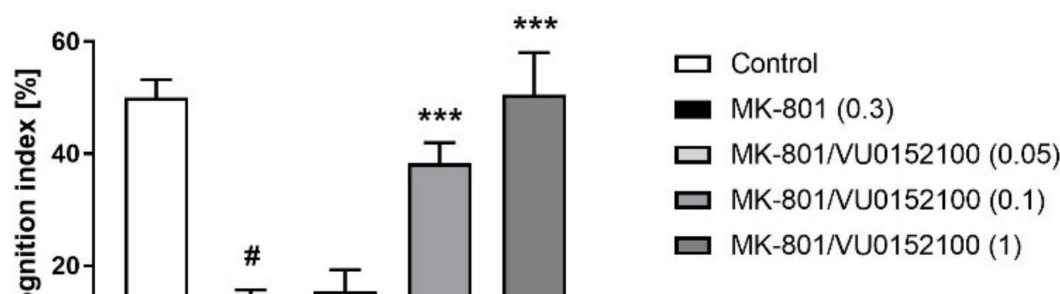

C

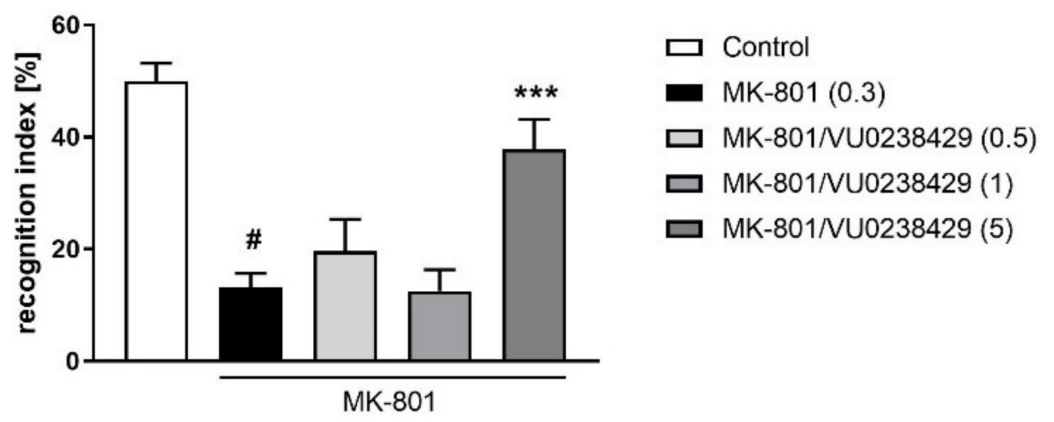

Figure 9. Activity of VU0357017 (A), VU0152100 (B), and VU0238429 (C) in the NOR test after seven days of administration. The data are presented as means \pm SEM. Doses of the compounds are indicated in parentheses. \# $p<0.001$ compared to control animals and ${ }^{*} p<0.05, * * *<0.001$ compared to MK-801-treated mice. 
In the Y-maze test, the activity of VU0357017 was observed at a dose of $5 \mathrm{mg} / \mathrm{kg}$ $\left(\mathrm{F}_{(3,36)}=3.795 ; p<0.05\right)$ but not at 0.5 or $1 \mathrm{mg} / \mathrm{kg}$. VU0152100 was only active at the dose $0.1\left(\mathrm{~F}_{(4,46)}=4.990 ; p<0.01\right)$ and VU0238429 was active at a dose of $5 \mathrm{mg} / \mathrm{kg}\left(\mathrm{F}_{(3,37)}=4.579\right.$; $p<0.01$ ) but not at 0.5 or $1 \mathrm{mg} / \mathrm{kg}$ (Figure 10).

A

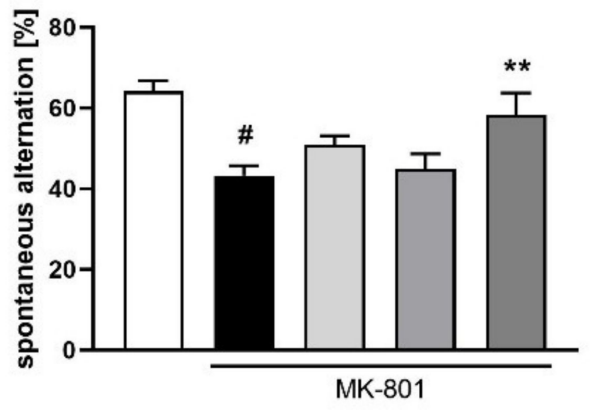

$\square$ Control

- MK-801 (0.3)

口MK-801/NU0357017 (0.5)

口 MK-801NU0357017 (1)

口 MK-801NU0357017 (5)

B

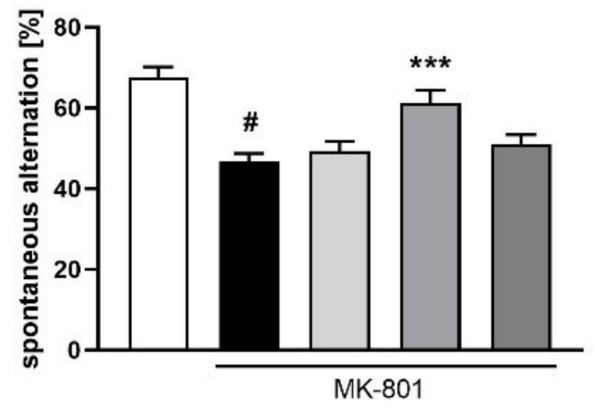

$\square$ Control

- MK-801 (0.3)

口 MK-801/VU0152100 (0.05)

口 MK-801/NU0152100 (0.1)

$\square \mathrm{MK}-801 / \mathrm{VU} 0152100(0.5)$

C

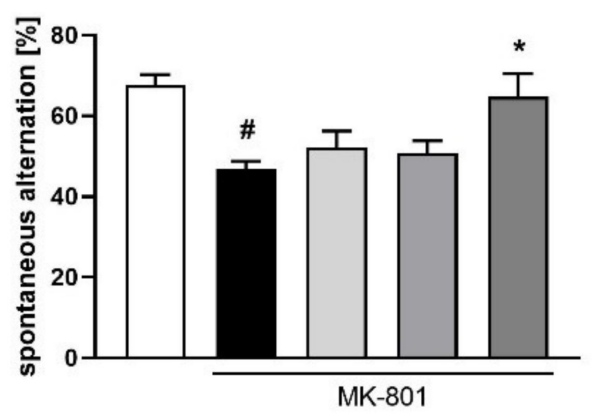

$$
\begin{aligned}
& \square \text { Control } \\
& \text { - MK-801 (0.3) } \\
& \text { 口 MK-801/NU0238429 (0.5) } \\
& \text { 口 MK-801NU0238429 (1) } \\
& \text { 口 MK-801NU0238429 (5) }
\end{aligned}
$$

Figure 10. Activity of VU0357017 (A), VU0152100 (B), and VU0238429 (C) in the Y-maze test after seven days of administration. The data are presented as means \pm SEM. Doses of the compounds are indicated in parentheses. \# $p<0.001$ compared to control animals and ${ }^{*} p<0.05,{ }^{* *} p<0.01$, *** $p<0.001$ compared to MK-801-treated mice.

2.3.3. Combined Administration of Muscarinic Activators and F15599 at Subeffective Doses

The combined administration of a subeffective dose of F15599 $(0.05 \mathrm{mg} / \mathrm{kg})$ with subeffective doses of VU0357017 $(0.15 \mathrm{mg} / \mathrm{kg})$, VU0152100 $(0.05 \mathrm{mg} / \mathrm{kg})$, or VU0238429 $(1 \mathrm{mg} / \mathrm{kg})$ reversed MK-801-induced disruptions in NOR test $\left(\mathrm{F}_{(1,28)}=10.7384, p<0.01\right.$; $\mathrm{F}_{(1,31)}=17.2759, p<0.001 ; \mathrm{F}_{(1,32)}=23.0644, p<0.001$, respectively) (Figure 11). 
A

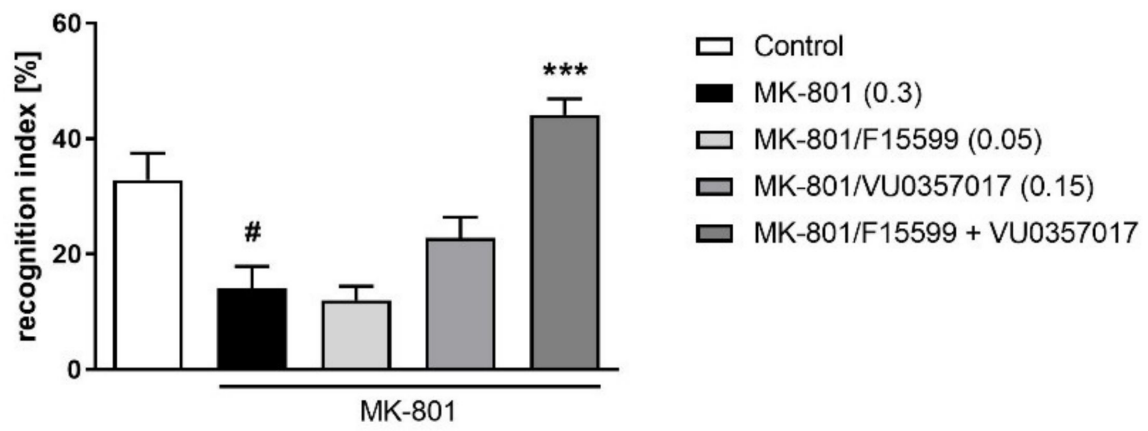

B

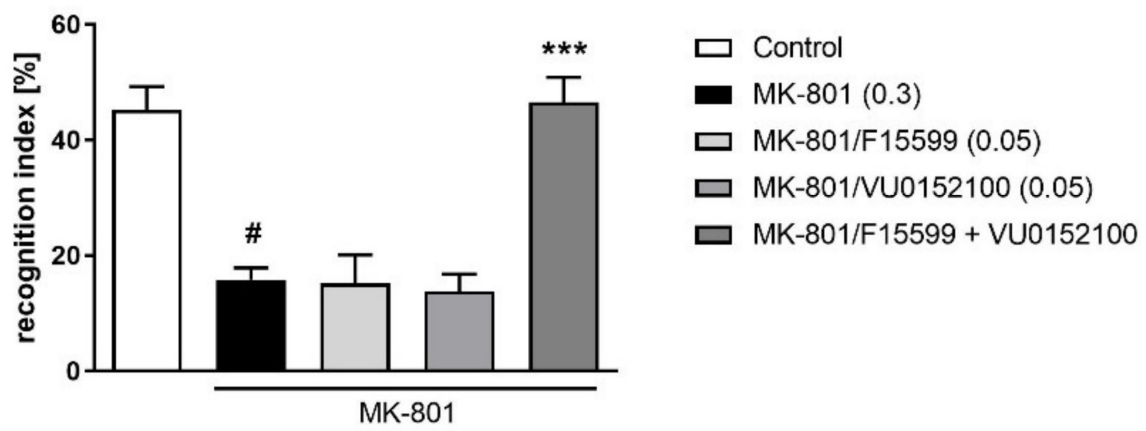

C

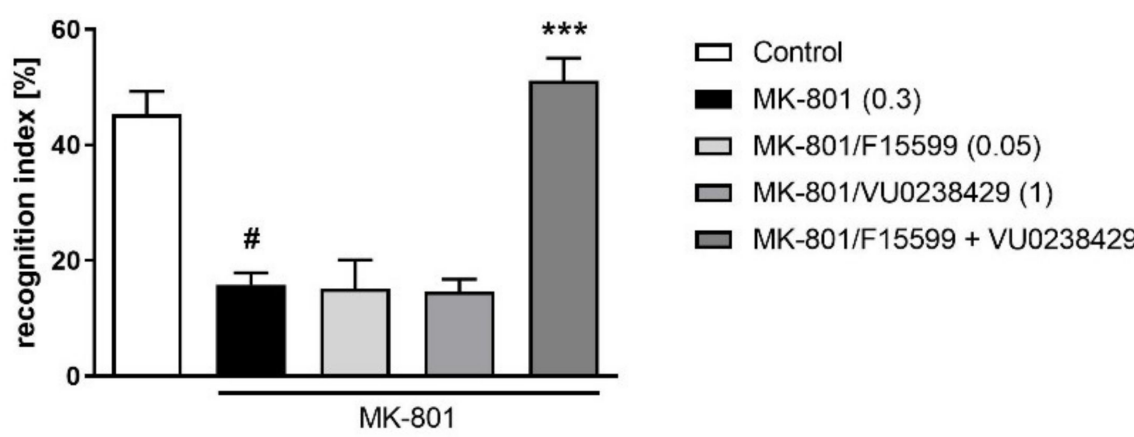

Figure 11. Activity of the combined administration of subeffective dose of F15599 with subeffective dose of VU0357017 (A), VU0152100 (B), or VU0238429 (C) in the NOR test after seven days of treatment. The data are presented as means \pm SEM. Doses of the compounds are indicated in parentheses. \# $p<0.01(\mathbf{A})$ or $\# p<0.001(\mathbf{B}, \mathbf{C})$ compared to control animals and ${ }^{* * *} p<0.001$ compared to MK-801-treated mice.

The combined administration of a subeffective dose of F15599 $(0.025 \mathrm{mg} / \mathrm{kg})$ with subeffective doses of VU0357017 (1 mg/kg), VU0152100 $(0.05 \mathrm{mg} / \mathrm{kg})$, or VU0238429 $(1 \mathrm{mg} / \mathrm{kg}$ ) did not reverse MK-801-induced disruptions in Y-maze (Figure 12). 
A

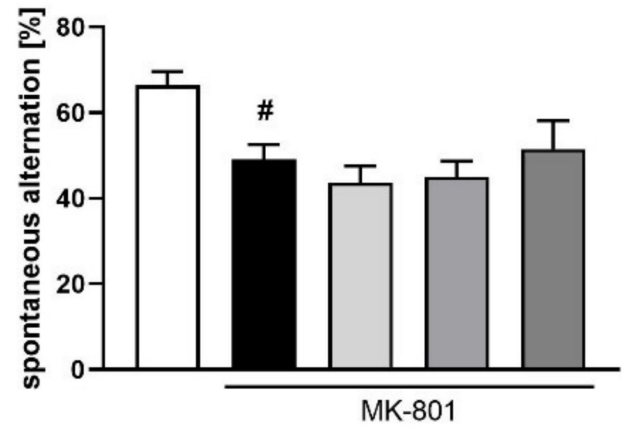

$\square$ Control

- MK-801 (0.3)

$\square$ MK-801/F15599 (0.025)

口 MK-801/VU0357017 (1)

$\square$ MK-801/F15599 + VU0357017

B

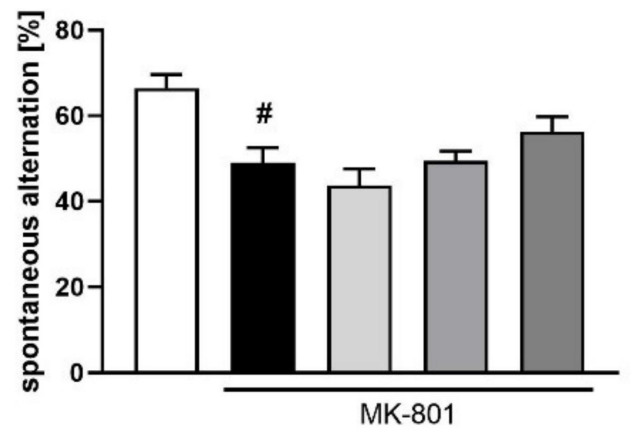

$\square$ Control

- MK-801 (0.3)

$\square \mathrm{MK}-801 / \mathrm{F} 15599(0.025)$

$\square \mathrm{MK}-801 / \mathrm{VU} 0152100(0.05)$

$\square$ MK-801/F15599 + VU0152100

C
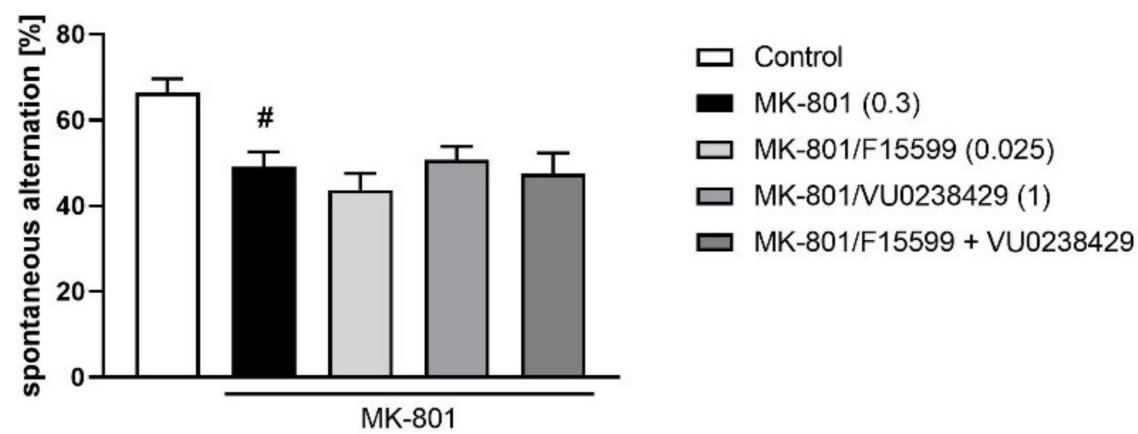

Figure 12. Activity of combined administration of subeffective dose of F15599 with subeffective dose of VU0357017 (A), VU0152100 (B), or VU0238429 (C) in the Y-maze test after seven days of treatment. The data are presented as means \pm SEM. Doses of the compounds are indicated in parentheses. $\# p<0.01$ compared to control animals.

\subsection{Pharmacokinetic Studies}

\subsubsection{Pharmacokinetic Analysis of F15599}

F15599 reached its maximal concentration in both plasma and FC after $15 \mathrm{~min}$ (27 and $48 \mathrm{ng} / \mathrm{mL}$, respectively). The drug was detected in plasma and brain up to $120 \mathrm{~min}$ after administration, and its concentration was still high $(24 \mathrm{ng} / \mathrm{mL}$ in the brain). Timedependent changes in the concentrations of $\mathrm{F} 15599$ and $\mathrm{T}_{1 / 2}, \mathrm{~T}_{\max }$, and $\mathrm{C}_{\max }$ are presented in Figure 13. 
A

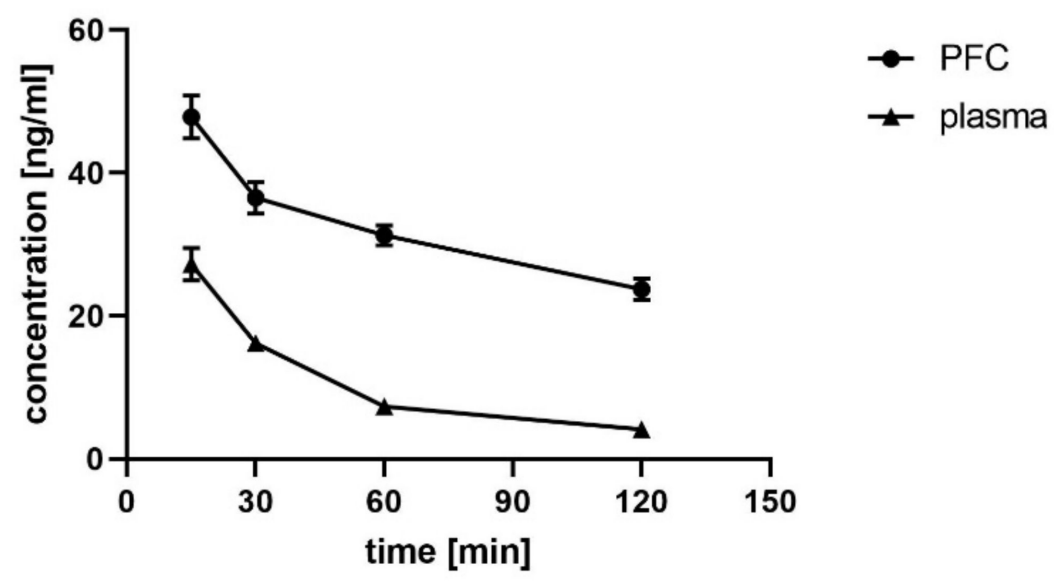

B

\begin{tabular}{|l|c|c|c|c|c|c|}
\hline & \multicolumn{2}{|c|}{$\mathrm{T}_{1 / 2}[\mathrm{~min}]$} & \multicolumn{2}{c|}{$\mathrm{T}_{\max }[\mathrm{min}]$} & \multicolumn{2}{c|}{$\mathrm{C}_{\max }[\mathrm{ng} / \mathrm{ml}]$} \\
\cline { 2 - 7 } & plasma & PFC & plasma & PFC & plasma & PFC \\
\hline F15599 $(0.1 \mathrm{mg} / \mathrm{kg})$ & 35 & 120 & 15 & 15 & 27 & 48 \\
\hline
\end{tabular}

Figure 13. Pharmacokinetic analysis of the ability of F15599 to penetrate the frontal cortex. Timedependent changes $(\mathbf{A})$ and $\mathrm{T}_{1 / 2}, \mathrm{~T}_{\max }$ and $\mathrm{C}_{\max }(\mathbf{B})$ are presented. F15599 was administered at a dose of $0.1 \mathrm{mg} / \mathrm{kg}$.

\subsubsection{Pharmacokinetic Analysis of Drug-Drug Interactions}

F15599 had the highest FC penetration among the tested ligands after acute administration at the top dose, reaching $620 \%$. Prolonged administration of the compound decreased FC penetration by ca. $50 \%$.

The percentage of FC penetration after acute administration of the compounds at the top doses alone was similar for VU0357017 and VU0238429 (67\% and 53\%, respectively). Only 7\% of VU0152100 accumulated in the FC. Prolonged administration of the compounds to animals treated with MK- 801 decreased the FC penetration ratio by ca. $50 \%$ for VU0357017 and VU0238429 (which was 36\% and 21\%, respectively), except for VU0152100 the penetration of which was almost $50 \%$ higher than after acute administration.

Acute, concomitant administration of subeffective doses of F15599 and VU0357017 or VU0238429 resulted in a decrease of FC penetration of VU0357017 (more than 50\%), VU0238429 ( 40\%). Penetration of F15599 decreased 50\%, when administered simultaneously with VU0152100 or VU0238429. On the contrary, FC penetration of VU0152100 increased more than $50 \%$ when administered concomitantly with F15599.

Chronic administration of subeffective doses of the compounds increased the brain penetration of F15599, but had no effect on muscarinic ligands.

The drug concentrations in plasma and FC and the FC penetration level after acute or chronic administration of the tested compounds either at the highest doses alone or at subeffective doses in combination are presented in Table 1. 
Table 1. Pharmacokinetic analysis of the FC penetration of the drugs administered at the highest doses alone and the combined administration of the compounds at the subeffective doses. The compounds were administered both acutely and for seven days along with MK-801.

\begin{tabular}{|c|c|c|c|c|c|c|c|}
\hline $\begin{array}{c}\text { Acute } \\
\text { Administration }\end{array}$ & $\begin{array}{l}\text { Plasma } \\
(\mathrm{ng} / \mathrm{mL})\end{array}$ & $\begin{array}{c}\text { PFC } \\
(\mathrm{ng} / \mathrm{mL})\end{array}$ & $\begin{array}{c}\text { PFC Penetration } \\
(\%)\end{array}$ & $\begin{array}{c}\text { Chronic } \\
\text { Administration }\end{array}$ & $\begin{array}{l}\text { Plasma } \\
(\mathrm{ng} / \mathrm{mL})\end{array}$ & $\begin{array}{c}\text { PFC } \\
(\mathrm{ng} / \mathrm{mL})\end{array}$ & $\begin{array}{c}\text { PFC Penetration } \\
(\%)\end{array}$ \\
\hline Top doses & \multicolumn{7}{|c|}{ Top doses } \\
\hline $\begin{array}{l}\text { VU0357017 } \\
\text { (5 mg/kg) }\end{array}$ & $107.28 \pm 7.65$ & $71.65 \pm 4.69$ & $67 \%$ & $\begin{array}{l}\text { VU0357017 } \\
(5 \mathrm{mg} / \mathrm{kg})\end{array}$ & $138.15 \pm 14.91$ & $50.33 \pm 4.62$ & $36 \%$ \\
\hline $\begin{array}{l}\text { VU0152100 } \\
(1 \mathrm{mg} / \mathrm{kg})\end{array}$ & $78.44 \pm 11.86$ & $5.71 \pm 1.51$ & $7 \%$ & $\begin{array}{l}\text { VU0152100 } \\
\text { (1 mg/kg) }\end{array}$ & $60.91 \pm 2.66$ & $7.85 \pm 0.53$ & $13 \%$ \\
\hline $\begin{array}{l}\text { VU0238429 } \\
(5 \mathrm{mg} / \mathrm{kg})\end{array}$ & $486 \pm 178$ & $256 \pm 32.06$ & $53 \%$ & $\begin{array}{l}\text { VU0238429 } \\
\text { (5 mg/kg) }\end{array}$ & $844.14 \pm 235$ & $179.20 \pm 24.98$ & $21 \%$ \\
\hline $\begin{array}{c}\text { F15599 } \\
(0.1 \mathrm{mg} / \mathrm{kg})\end{array}$ & $2.95 \pm 0.4$ & $18.29 \pm 0.84$ & $620 \%$ & $\begin{array}{c}\text { F15599 } \\
(0.1 \mathrm{mg} / \mathrm{kg})\end{array}$ & $6.98 \pm 0.7$ & $21.57 \pm 1.26$ & $309 \%$ \\
\hline $\begin{array}{l}\text { Subeffective } \\
\text { doses }\end{array}$ & \multicolumn{7}{|c|}{$\begin{array}{l}\text { Subeffective } \\
\text { doses }\end{array}$} \\
\hline $\begin{array}{c}\text { F15599 } \\
(0.05 \mathrm{mg} / \mathrm{kg})\end{array}$ & $1.77 \pm 0.24$ & $11.26 \pm 1.25$ & $636 \%$ & \multirow{2}{*}{$\begin{array}{c}\text { F15599 } \\
(0.05 \mathrm{mg} / \mathrm{kg}) \\
\text { VU0357017 } \\
(0.15 \mathrm{mg} / \mathrm{kg})\end{array}$} & $1.9 \pm 0.23$ & $18.01 \pm 2.23$ & $948 \%$ \\
\hline $\begin{array}{l}\text { VU0357017 } \\
(1 \mathrm{mg} / \mathrm{kg})\end{array}$ & $7.19 \pm 0.24$ & $2.25 \pm 0.56$ & $31 \%$ & & $5.13 \pm 0.38$ & $2.34 \pm 0.255$ & $46 \%$ \\
\hline $\begin{array}{c}\text { F15599 } \\
(0.05 \mathrm{mg} / \mathrm{kg})\end{array}$ & $5.32 \pm 0.39$ & $18.15 \pm 0.74$ & $341 \%$ & \multirow{2}{*}{$\begin{array}{c}\text { F15599 } \\
(0.05 \mathrm{mg} / \mathrm{kg}) \\
\text { VU0152100 } \\
(0.05 \mathrm{mg} / \mathrm{kg})\end{array}$} & $6.86 \pm 0.38$ & $32.12 \pm 1.27$ & $468 \%$ \\
\hline $\begin{array}{l}\text { VU0152100 } \\
(0.25 \mathrm{mg} / \mathrm{kg})\end{array}$ & $7.62 \pm 0.63$ & $1.4 \pm 0.11$ & $18 \%$ & & $3.77 \pm 0.26$ & $0.54 \pm 0.07$ & $14 \%$ \\
\hline $\begin{array}{c}\text { F15599 } \\
(0.05 \mathrm{mg} / \mathrm{kg})\end{array}$ & $5.1 \pm 0.37$ & $16.58 \pm 0.53$ & $325 \%$ & \multirow{2}{*}{$\begin{array}{c}\text { F15599 } \\
(0.05 \mathrm{mg} / \mathrm{kg}) \\
\text { VU0238429 } \\
(1 \mathrm{mg} / \mathrm{kg})\end{array}$} & $6.5 \pm 0.44$ & $32.35 \pm 1.14$ & $498 \%$ \\
\hline $\begin{array}{l}\text { VU0238429 } \\
\text { (1 mg/kg) }\end{array}$ & $119.91 \pm 13.9$ & $43.12 \pm 1.81$ & $36 \%$ & & $35 \pm 8.89$ & $5.13 \pm 0.83$ & $15 \%$ \\
\hline
\end{tabular}

\section{Discussion}

The present study aimed to investigate the benefits of simultaneous activation of 5$\mathrm{HT}_{1 \mathrm{~A}}$ and muscarinic receptors after the combined administration of subeffective doses of their activators. To date, this study is the first to document the activity of a $5-\mathrm{HT}_{1 \mathrm{~A}}$-biased agonist, F15599, in tests assessing cognition and the first pharmacokinetic analysis showing the brain penetrating abilities of the compound.

The efficacy of F15599 in ameliorating MK-801-induced disruptions in NOR was evident both after acute and repeated administration, while in the Y-maze, the compound was active only after acute and not repeated administration. Previously it was shown that the compound ameliorated PCP-induced deficits during the reversal phase of the learning task and in the hole-board test [25]. In our subsequent studies in which the effectiveness of the simultaneous administration of F15599 with the activators of muscarinic receptors was investigated, doses of F15599 lower than $0.1 \mathrm{mg} / \mathrm{kg}$ were used, as at doses greater than $0.16 \mathrm{mg} / \mathrm{kg}$, F15599 induced some of the adverse effects on rats related to serotonergic syndrome [19].

The experiments were a continuation of our previous research in which the synergistic actions of muscarinic and metabotropic glutamate receptor activation were observed in animal models of schizophrenia [21-24].

No synergistic activity of the combined, single administration of low, subeffective doses of F15599, together with subeffective doses of any muscarinic activator was noticed. The results are in contrast with the majority of our earlier studies in which the efficacy of combined administration of subeffective doses of the 5- $\mathrm{HT}_{1 \mathrm{~A}}$ agonist (R,S)-8-OH-DPAT potentiated the procognitive activity of subeffective doses of several mGlu activators e.g., LSP4-2022, LY379268 [7,13-15]. In parallel experiments, the activity of muscarinic 
receptor activators was blocked by WAY100635, a 5- $\mathrm{HT}_{1 \mathrm{~A}}$ receptor antagonist, indicating the 5-HT $\mathrm{HA}_{1 \mathrm{~A}}$-dependent activity of VU0357017, VU0152100, and VU0238429.

Subsequently, the efficacy of F15599 and muscarinic receptors activators was observed after prolonged (7 days) administration of the compounds along with MK-801. Under this treatment regimen, the activity of drugs in NOR was evident at lower doses than after acute administration [21-24] and was also noticed in the Y-maze test indicating, that lower doses of the compounds are sufficient to prevent memory impairments induced by prolonged MK-801 administration. The simultaneous prolonged administration of subeffective doses of F15599 with VU03567017, VU0152100, and VU0238429 reversed MK-801-induced disruptions in NOR, but not in the Y-maze test.

Overall, our results indicate that the animals' responses both to the amnestic potency of MK-801 and to the preventive effectivity of the tested compounds were evidently weaker in the Y-maze test than in the NOR test. To some extent, this result may be due to the activation of slightly different pathways in the brain that regulate animals' performance on each test and different types of cognitive processes activated by these two tasks (spatial working memory in the Y-maze and short-term recognition memory in the NOR test) [26-28].

An interesting observation reported in the present study and previously [24] concerns a change in the sensitivity of animals to the action of muscarinic ligands after chronic administration of MK-801. The impairments in cognition induced by blockade of NMDA receptors for seven days were reversed by chronic administration of $\mathrm{M}_{1}, \mathrm{M}_{4}$, or $\mathrm{M}_{5}$ activators at lower doses than those needed to prevent memory dysfunction induced with acute administration of MK-801. Similar observations were reported earlier for $\mathrm{mGlu}_{2}$ activator, LY487379 [24]. The activity of F15599 was similar in both experimental schedules. This finding might be of clinical importance, indicating a low risk of tolerance development and the possibility of decreasing drug dosing with the duration of the treatment.

The next part of investigations aimed to confirm or exclude putative drug-drug interactions that could occur after the combined administration of the compounds.

In contrast to our earlier studies, the analysis was performed in the frontal cortex, the structure postulated to be involved in higher processing in the brain [29,30], with high expression of muscarinic receptors [21,31,32], and the site of the preferential action of the 5- $\mathrm{HT}_{1 \mathrm{~A}}$-biased agonist F15599 [19].

Pharmacokinetic studies of F15599 revealed its rapid brain penetration (15 min) with a relatively long half-life in the FC (120 min) and high FC penetrability, as suggested in the literature [19,20]. Both VU0357017 and VU0238429 displayed high FC penetration, reaching $67 \%$ and $53 \%$, respectively, and the FC/plasma ratio for VU0152100 was 7\%. Compared to earlier studies performed both in our laboratory [21,22,24] and by others [33-35] in which the whole-brain penetrability of muscarinic ligands was investigated, the brain/plasma ratios for both VU0357017, an $\mathrm{M}_{1}$ allosteric agonist, and VU0152100, an $\mathrm{M}_{4}$ PAM, were similar to the FC/plasma ratio [21]. VU0238429, the $\mathrm{M}_{5}$ PAM, appears to preferentially accumulate in the FC. Earlier studies indicated relatively weak brain penetration of the compound, which was not higher than $8 \%$ [24,34]. The more than 6 times higher penetration to the FC would explain the ability of this compound to reverse MK-801-induced memory impairments, and confirms its putative therapeutic potency.

The acute administration of the combinations at subeffective doses resulted in decreased FC penetration of VU0357017, VU0238429, and F15599 compared to the FC/plasma ratio observed after the acute administration of the top doses of each compound alone. This result potentially indicates possible drug-drug interactions and may explain the lack of interaction in the behavioral tests described above. 
Prolonged MK-801 administration decreased brain penetration by up to $50 \%$ for all the compounds at the top doses (except VU0152100) compared to single administration. This result contradicts behavioral studies in which lower doses of the compounds were active. Further studies are needed to understand this phenomenon.

The repeated administration of MK-801 and the combinations at subeffective doses did not affect FC penetration properties in comparison to acute administration.

The present results fit the trends indicating the potential of muscarinic receptors as targets for antipsychotic drugs, which were first presented clinically by Shekhar et al. [36] for xanomeline and later developed by Karuna Therapeutics (https:/ / clinicaltrials.gov/ct2/s how /NCT03697252, access date: 18 June 2021). Karuna Therapeutics's KarXT circumvents the adverse effects of xanomeline, as the drug is combined with an FDA-approved muscarinic antagonist (trospium) to reduce off-target activity related to activation of peripheral $\mathrm{M}_{2}$ and $\mathrm{M}_{3}$ receptors [37,38]. Subsequent studies indicated that the selective activation of $\mathrm{M}_{1}, \mathrm{M}_{4}$, or $\mathrm{M}_{5}$ receptors (presumed to be preferentially expressed in the brain [32]) was a better and safer alternative to xanomeline. To date, these and our recent studies are the most relevant confirming the activity of the ligands in animal models of schizophrenia-related cognitive symptoms.

As the brains of patients with schizophrenia display dysfunctions in receptor expression or excitability (for a review, see: [39]), a certain benefit may be the simultaneous stimulation of two different receptors, as proposed in many of our previous papers [39]. As the $5-\mathrm{HT}_{1 \mathrm{~A}}$ receptor is postulated to play an essential role in cognition, here, we show that simultaneous, chronic activation of muscarinic, and $5-\mathrm{HT}_{1 \mathrm{~A}}$ receptors may exert a therapeutic effect on some forms of learning at relatively low doses and offer a possibility to reduce the adverse effects observed for xanomeline or (R,S)-8-OH-DPAT alone, thus eliminating the need to use add-on drugs, e.g., trospium.

To explain the mechanism of action of investigated ligands we followed the hypothesis of NMDA receptor insufficiency as the main disturbance responsible for schizophrenia. The glutamatergic hypothesis of schizophrenia was formulated based on the work of Maria and Arvid Carlsson, who were first to suggest that aside from dopaminergic hyperactivity, glutamatergic dysregulation could be one of the main causes of the disease [40]. The hypothesis assumes that glutamatergic hyperactivity in the brain is associated with the deficiency of NMDA receptors, located on the inhibitory GABAergic interneurons [41-45]. According to this hypothesis disinhibited thalamocortical glutamatergic neurotransmission was the core cause of enhanced release of the other neurotransmitters, including dopamine (increased dopamine release was initially proposed by Carlsson as the main cause of schizophrenia and contributed to the formulation of dopaminergic theory of schizophrenia which was the first hypothesis of the disease introduced in 1977 [46]). Therefore, the inhibition of increased glutamate release in the cortex can be proposed as the primary mechanism of the action of the ligands administered either alone or in combinations (schematically presented on Figure 14). Activation of 5- $\mathrm{HT}_{1 \mathrm{~A}}$ receptors expressed postsynaptically on cortical glutamatergic neurons inhibits the activity of those neurons and thus counteracts the glutamatergic hyperexcitability. Additionally, stimulation of $\mathrm{M}_{4}$ receptors located presynaptically on glutamatergic terminals leads to the inhibition of excessive glutamate release. Activation of $\mathrm{M}_{1}$ or $\mathrm{M}_{5}$ receptors expressed on GABAergic interneurons leads to an increase of GABA release and thus may compensate for NMDA receptor-dysfunction. Overall, as the final result of the treatment dopaminergic-glutamatergic balance in the brain should be restored. 


\section{A}

(1)

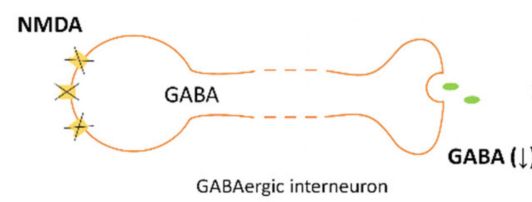

GABAergic interneuron

(2)

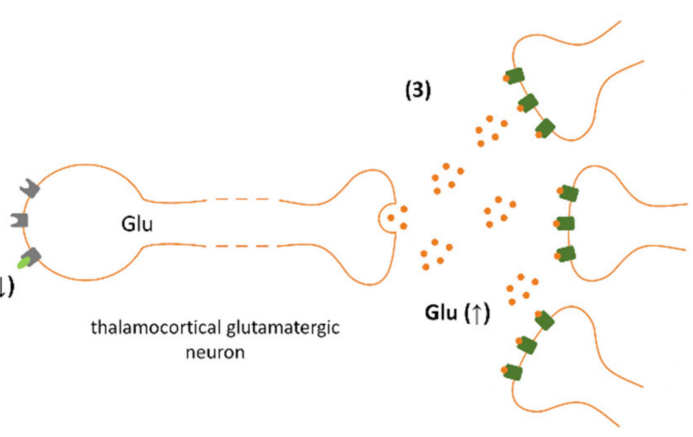

B

(4)

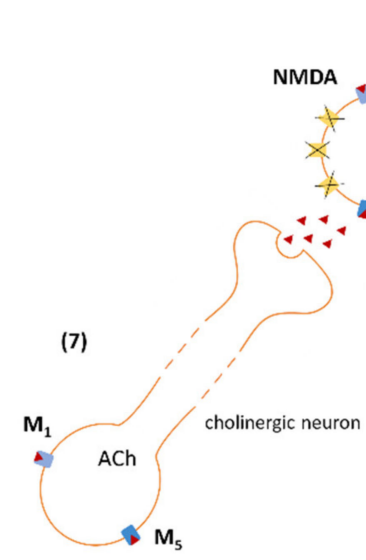

(2)

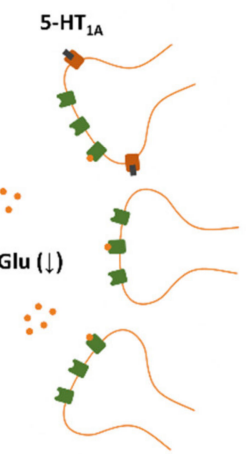

cortical pyramidal neurons

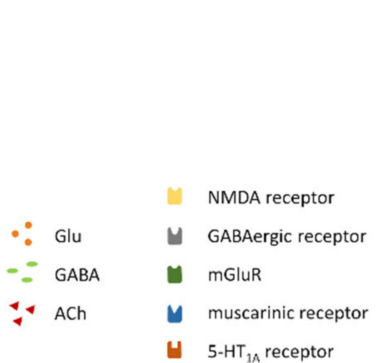

Figure 14. Proposed mechanism of action of investigated combinations (basic scheme adapted from Conn et al. [43]). (A) Impaired effect of glutamate on dysfunctional NMDA receptors located on GABAergic neurons (1), results in decreased GABA release (2), disinhibition of subsequent thalamocortical glutamatergic innervation and overactivation of pyramidal glutamatergic neurons in the cortex (3). (B) $\mathrm{M}_{1}$ and $\mathrm{M}_{5}$ receptors may be expressed on GABAergic neurons (4), and thus, their activation by VU0357017 or VU0238429 counteracts NMDA-related impairments (both $\mathrm{M}_{1}$ and $\mathrm{M}_{5}$ receptors are linked to Gq protein and thus are excitatory in nature); additionally, the ligands may activate $\mathrm{M}_{1}$ or $\mathrm{M}_{5}$ receptors expressed on cholinergic neurons innervating GABAergic interneurons (7). 5- $\mathrm{HT}_{1 \mathrm{~A}}$ receptors are expressed postsynaptically on glutamatergic neurons in the cortex (5). The receptors are linked to Gi proteins; thus, their activation by F15599 inhibits neuronal activity and counteracts the hyperexcitability observed in individuals with schizophrenia. $\mathrm{M}_{4}$ receptors are expressed presynaptically on glutamatergic terminals; their stimulation by VU0152100 activates Gi protein, which are inhibitory in nature and leads to the inhibition of glutamate release (6).

\section{Materials and Methods}

\subsection{Animals and Housing}

Male Albino Swiss mice (Charles River, Sulzfeld, Germany) weighing 20-25 g at the beginning of the experiments were used in the studies. The animals were housed in a room with a 12:12 h light-dark cycle at a temperature of $22 \pm 1{ }^{\circ} \mathrm{C}$ with food and water available ad libitum. The experimental groups consisted of 8-10 animals. All drugs were administered intraperitoneally (i.p.) at a volume of $10 \mathrm{~mL} / \mathrm{kg}$. The behavioral experiments were performed by an observer who was blinded to the treatment. The procedures were conducted in accordance with the European Communities Council Directive of 22 Septem- 
ber 2010 (2010/63/EU) and Polish legislation acts concerning animal experimentation and were approved by the II Local Ethics Committee by the Maj Institute of Pharmacology, Polish Academy of Sciences in Krakow (15/2020, 240/2020).

\subsection{Drugs}

MK-801 (Hello Bio, Bristol, UK), F15599 (NLX-101) (MedChemExpress) and VU0357017 hydrochloride (Biorbyt) were dissolved in $0.9 \% \mathrm{NaCl}$. VU0152100 (Biorbyt) and VU0238429 (Tocris) were dissolved in $10 \%$ Tween 80 in $0.9 \% \mathrm{NaCl}$. When the administration of the tested compounds was omitted (control and MK-801 groups), the animals received appropriate vehicles. The doses used in behavioral experiments were based on our previous studies $[22,23]$ and available data $[25,47,48]$.

\subsection{Treatment Regimen}

In acute experiments, the tested compounds (alone or in combination) were administered $30 \mathrm{~min}$ before MK-801 $(0.3 \mathrm{mg} / \mathrm{kg})$, which was administered $30 \mathrm{~min}$ before the test or training trial $\left(\mathrm{T}_{1}\right)$ in the NOR test. In chronic experiments, the tested compounds (alone or in combination) and MK-801 were administered for seven days. Behavioral tests were performed on the eighth day. The treatment schedules are schematically presented in Figure 1.

\subsection{Novel Object Recognition Test}

The NOR test was performed as described previously [21,24]. Briefly, the habituation, training and test trial were carried out in a dark room in a black, plastic rectangular arena illuminated with a 355 lux bulb. During the habituation trial, the animals were allowed to explore the arena in the absence of objects (10 $\mathrm{min} /$ day for 2 days). The next day, the training $\left(\mathrm{T}_{1}\right)$ and test $\left(\mathrm{T}_{2}\right)$ trials were performed. Throughout $\mathrm{T}_{1}$, mice were allowed to freely explore two identical objects ( $5 \mathrm{~min}$ ), one of which was subsequently replaced by a novel object in $\mathrm{T}_{2}(1 \mathrm{~h}$ later, $5 \mathrm{~min}$ of exploration). Time spent exploring (i.e., sniffing or touching) the familiar $\left(\mathrm{T}_{\text {familiar }}\right)$ or novel object $\left(\mathrm{T}_{\text {novel }}\right)$ was measured by a trained observer, and then the recognition index was calculated for each mouse $\left[\left(T_{\text {novel }}-T_{\text {familiar }}\right) /\right.$ $\left.\left(\mathrm{T}_{\text {familiar }}+\mathrm{T}_{\text {novel }}\right)\right] \times 100$.

\subsection{Y-Maze}

The Y-maze was performed using the methods described by Miedel et al. and Kraeuter et al. [26,49] with minor modifications. A black, wooden Y-shaped apparatus with equal length arms (labeled A, B, or C) spaced 120 apart was used in the behavioral experiment. Visual clues were placed inside the maze and mounted to the back wall of each arm. The experiment was performed in a well-lit room. The mice were placed in the same starting arm and were allowed to freely explore the maze for $8 \mathrm{~min}$. After each trial, the maze was wiped clean. The sequence and the number of arm entries were recorded to calculate the percentage of spontaneous alternations using the following formula: [(Number of alternations) $/$ (Total arm entries -2 ) $] \times 100$. An arm entry was scored if the animal entered the arm with all paws. Consecutive entries into three distinct arms were scored as an alternation (e.g., $\mathrm{ACB}$, but not $\mathrm{ACA}$ ) in which sequences could overlap (e.g., $\mathrm{ACBACABAC}$ represents five alternations).

\subsection{Pharmacokinetic Studies}

The experiment was performed using the methods described by Bridges et al. [34] and in our previous studies [21,22,24].

The pharmacokinetic analysis was performed in the blood and prefrontal cortex. Blood was collected from the inferior vena cava, transferred to an EDTA-coated tube (Sarstedt) and centrifuged at $3500 \times \mathrm{g}$ rpm for $10 \mathrm{~min}$ at RT. Plasma and FC samples were stored at $-80{ }^{\circ} \mathrm{C}$ until analysis. 


\subsubsection{Pharmacodynamic Studies of F15599 after Acute Administration}

The drug was administered at a dose of $0.1 \mathrm{mg} / \mathrm{kg}$; brain and tissue samples were collected 15, 30, 60, and 120 min after administration.

\subsubsection{Pharmacokinetic Studies after Acute Administration of the Combined Treatment}

Each compound was administered alone at the top dose (F15599-0.1 mg/kg, VU0357017-5 mg $/ \mathrm{kg}$, VU0152100-1 mg $/ \mathrm{kg}$, and VU0238429-5 mg $/ \mathrm{kg}$ ) and in combinations of muscarinic ligands at subeffective doses with F15599 at subeffective dose (F15599 + VU0357017 0.05 and $1 \mathrm{mg} / \mathrm{kg}$, F15599 + VU0152100 0.05 and $0.25 \mathrm{mg} / \mathrm{kg}$, F15599 + VU0238429 0.05 and $1 \mathrm{mg} / \mathrm{kg}$ ). The FC and blood were collected $30 \mathrm{~min}$ after administration.

\subsubsection{Pharmacokinetic Studies after Prolonged Administration of Combined Treatment}

The investigated compounds were administered alone at the top dose (F15599$0.1 \mathrm{mg} / \mathrm{kg}$, VU0357017—5 mg/kg, VU0152100—1 mg/ $\mathrm{kg}$, and VU0238429—5 mg/kg) and in combinations of muscarinic ligands at subeffective doses with F15599 at subeffective dose (F15599 + VU0357017 0.05 and $0.15 \mathrm{mg} / \mathrm{kg}$, F15599 + VU0152100 0.05 and $0.05 \mathrm{mg} / \mathrm{kg}$, F15599 + VU0238429 0.05 and $1 \mathrm{mg} / \mathrm{kg}$ ). The FC and blood were collected on the eighth day, $30 \mathrm{~min}$ after administration. All mice were parallelly treated with MK-801 $(0.3 \mathrm{mg} / \mathrm{kg})$ for seven consecutive days.

On the day of analysis, frozen whole mouse brain tissues were weighed and homogenized in 1:2 $(w / v)$ volumes of ice-cold acetonitrile containing $0.1 \%$ FA and the internal standard mix. Samples were homogenized using a Metal Bead Lysing Matrix, vortexed for $1 \mathrm{~min}$, shaken for $20 \mathrm{~min}$ at $4{ }^{\circ} \mathrm{C}$ on Thermomixer $\mathrm{C}$, and centrifuged at $14,000 \times \mathrm{g} \mathrm{rpm}$ for $20 \mathrm{~min}$ at $4{ }^{\circ} \mathrm{C}$. Finally, $50 \mu \mathrm{L}$ of supernatant were diluted with $0.1 \%$ FA in water $(1: 1, v / v)$ and analyzed using HPLC/MS/MS.

The sample extraction of plasma $(20 \mu \mathrm{L})$ was performed after spiking with the internal standard mix using the protein precipitation method and three volumes of ice-cold acetonitrile containing $0.1 \%$ formic acid. The extract was vortexed, incubated on ice for $20 \mathrm{~min}$ and centrifuged at $14,000 \times g \mathrm{rpm}$ for $20 \mathrm{~min}$ at $4{ }^{\circ} \mathrm{C}$. The supernatant was diluted with $0.1 \% \mathrm{FA}$ in water $(1: 1, v / v)$ and analyzed by means of HPLC/MS/MS using a QTRAP 4500 (AB Sciex) mass spectrometer in positive ion mode in Multiple Reaction Monitoring (MRM screening) coupled with UHPLC (NEXERA XR, Shimadzu). Chromatographic separation was achieved on a Synergi $4 \mu \mathrm{m}$ Fusion-RP 80 A $50 \times 2 \mathrm{~mm}$ (Phenomenex) column at a flow rate of $0.2 \mathrm{~mL} / \mathrm{min}$. The gradient program was as follows: $20 \% \mathrm{~B}(0.3 \mathrm{~min}), 20-100 \% \mathrm{~B}$ (1.7 min), 100\% B (3 min), 100-20\% B (0.1 min), 20\% B (2 min), solvent A (95:5:0.1\% formic acid in water:methanol) and solvent $B$ (methanol containing $0.1 \%$ formic acid). The column temperature was set to $40^{\circ} \mathrm{C}$. Analyst software was used to control the instrument and collect data. The ion transfer tube temperature was $300^{\circ} \mathrm{C}$. The spray voltage, collision energy, declastering potential, and gas parameters were optimized to achieve the maximal response using the test compounds. Selected reaction monitoring was carried out using the transition parameters. Calibration curves were constructed, and a linear response was obtained in the range of $0.25-500 \mathrm{ng} / \mathrm{mL}$ (VU357017, VU0152100, and F15599) and $1.25-2500 \mathrm{ng} / \mathrm{mL}$ (VU0238429) by spiking known amounts of each compound in blank brain homogenates and plasma. For VU0357017 and F15599 IS VU0152100 was used as internal standard. Sample concentration of internal standard was $100 \mathrm{ng} / \mathrm{mL}$ for IS VU0238429 and $50 \mathrm{ng} / \mathrm{mL}$ for IS VU0152100.

Brain penetration was calculated as FC/plasma ratio $\times 100 \%$.

\subsection{Statistics}

The statistical analysis was performed using GraphPad Prism v.9.1.0 or TIBCO Statistica 13.3 software. The results of the dose-dependent studies were analyzed with one-way ANOVA followed by Dunnett's post hoc comparison. The results of interaction studies were analyzed with two-way ANOVA followed by Tukey's post hoc for unequal $\mathrm{N}$ comparison. 


\subsection{Software}

Marvin JS (ChemAxon, https://chemaxon.com/products/marvin-js, access date: 1 August 2021) was used to draw chemical structures in Figure 1.

\section{Conclusions}

The present studies show the potential benefit of using muscarinic and serotonergic ligands in the treatment of cognitive symptoms of schizophrenia. The activation of muscarinic $\mathrm{M}_{1}, \mathrm{M}_{4}$, and $\mathrm{M}_{5}$ receptors prevented MK-801-induced memory disruption in NOR and Y-maze tests both after acute and chronic administration of their activators, VU0357017, VU0152100, and VU0238429, respectively. The efficacy of the compounds was observed at much lower doses after prolonged administration when compared to acute treatment and this was accompanied with better FC penetration. Such discrepancy was not observed in the case of 5- $\mathrm{HT}_{1 \mathrm{~A}}$ activator, $\mathrm{F} 15599$, preferentially binding to the receptors expressed in the frontal cortex.

Simultaneous acute administration of the non-effective doses of the muscarinic activators with F15599 was not effective in neither NOR or Y-maze test. In contrast, prolonged simultaneous administration of the subeffective doses of the compounds along with MK801 prevented MK-801-induced memory disruption at the same way as the top doses given alone. Pharmacokinetic analysis revealed decreased FC penetration of the compounds after simultaneous, acute administration, and may suggest on some drug-drug interaction that might influence drugs' efficacies. Such an effect was not observed after prolonged administration of the combinations. No synergistic activity of the combinations was observed in Y-maze, neither after acute nor prolonged administration.

Taken together the proposed treatment, based on the chronic administration of the muscarinic ligands with 5-HT1A agonist may be proposed for the treatment of cognitive decline observed in schizophrenic patients. Importantly, much lower doses of the compounds are needed for chronic treatment to induce therapeutic effect, which limits the possibility to induce adverse effects or development of tolerance. Moreover, combined treatment can be more effective when the expression or the function of particular receptor subtypes is disturbed due to pathological state, as the compounds can compensate each other's action.

Author Contributions: Investigation, P.C., A.R. and G.B.; Data curation, P.C. and J.M.W.; Writingoriginal draft preparation, P.C. and J.M.W.; Writing - review and editing, P.C. and J.M.W.; Supervision, J.M.W. and L.K.; Funding acquisition, P.C. and L.K. All authors have read and agreed to the published version of the manuscript.

Funding: This research was funded by National Science Centre, grant no 2018/31/N/NZ7/03646 (Preludium 16), statutory funds of Maj Institute of Pharmacology, Polish Academy of Sciences, and Polish Ministry of Education and Science, grant no DIR/WK/2017/01. The APC was funded by Medical University of Gdańsk.

Conflicts of Interest: The authors declare no conflict of interest. The funders had no role in the design of the study; in the collection, analyses, or interpretation of data; in the writing of the manuscript, or in the decision to publish the results.

\section{References}

1. Sheffield, J.M.; Karcher, N.R.; Barch, D.M. Cognitive Deficits in Psychotic Disorders: A Lifespan Perspective. Neuropsychol. Rev. 2018, 28, 509-533. [CrossRef]

2. Owen, M.J.; Sawa, A.; Mortensen, P.B. Schizophrenia. Lancet 2016, 388, 86-97. [CrossRef]

3. Zanelli, J.; Mollon, J.; Sandin, S.; Morgan, C.; Dazzan, P.; Pilecka, I.; Marques, T.R.; David, A.S.; Morgan, K.; Fearon, P.; et al. Cognitive change in schizophrenia and other psychoses in the decade following the first episode. Am. J. Psychiatry 2019, 176, 811-819. [CrossRef]

4. Millan, M.J.; Agid, Y.; Brüne, M.; Bullmore, E.T.; Carter, C.S.; Clayton, N.S.; Connor, R.; Davis, S.; Deakin, B.; Derubeis, R.J.; et al. Cognitive dysfunction in psychiatric disorders: Characteristics, causes and the quest for improved therapy. Nat. Rev. Drug Discov. 2012, 11, 141-168. [CrossRef] 
5. Mauri, M.C.; Paletta, S.; Maffini, M.; Colasanti, A.; Dragogna, F.; Di Pace, C.; Altamura, A.C. Clinical pharmacology of atypical antipsychotics: An update. EXCLI J. 2014, 13, 1163-1191.

6. Horiguchi, M.; Miyauchi, M.; Neugebauer, N.M.; Oyamada, Y.; Meltzer, H.Y. Prolonged reversal of the phencyclidine-induced impairment in novel object recognition by a serotonin (5-HT)1A-dependent mechanism. Behav. Brain Res. 2016, 301, 132-141. [CrossRef]

7. Wierońska, J.M.; Sławińska, A.; Łasoń-Tyburkiewicz, M.; Gruca, P.; Papp, M.; Zorn, S.H.; Doller, D.; Kłeczek, N.; NoworytaSokołowska, K.; Gołembiowska, K.; et al. The antipsychotic-like effects in rodents of the positive allosteric modulator Lu AF21934 involve 5-HT1A receptor signaling: Mechanistic studies. Psychopharmacology 2015, 232, 259-273. [CrossRef]

8. Nagai, T.; Murai, R.; Matsui, K.; Kamei, H.; Noda, Y.; Furukawa, H.; Nabeshima, T. Aripiprazole ameliorates phencyclidineinduced impairment of recognition memory through dopamine D1 and serotonin 5-HT1A receptors. Psychopharmacology 2009, 202, 315-328. [CrossRef] [PubMed]

9. Mutlu, O.; Ulak, G.; Celikyurt, I.K.; Akar, F.Y.; Erden, F.; Tanyeri, P. Effects of olanzapine, sertindole and clozapine on MK-801 induced visual memory deficits in mice. Pharmacol. Biochem. Behav. 2011, 99, 557-565. [CrossRef]

10. Ohno, Y. Therapeutic Role of 5-HT1A Receptors in The Treatment of Schizophrenia and Parkinson's Disease. CNS Neurosci. Ther. 2011, 17, 58-65. [CrossRef] [PubMed]

11. Meltzer, H.Y.; Horiguchi, M.; Massey, B.W. The role of serotonin in the NMDA receptor antagonist models of psychosis and cognitive impairment. Psychopharmacology 2011, 213, 289-305. [CrossRef]

12. Meltzer, H.Y.; Rajagopal, L.; Huang, M.; Oyamada, Y.; Kwon, S.; Horiguchi, M. Translating the N-methyl-d-aspartate receptor antagonist model of schizophrenia to treatments for cognitive impairment in schizophrenia. Int. J. Neuropsychopharmacol. 2013, 16, 2181-2194. [CrossRef]

13. Wierońska, J.M.; Acher, F.C.; Sławińska, A.; Gruca, P.; Łasoń-Tyburkiewicz, M.; Papp, M.; Pilc, A. The antipsychotic-like effects of the mGlu group III orthosteric agonist, LSP1-2111, involves 5-HT1A signalling. Psychopharmacology 2013, 227, 711-725. [CrossRef]

14. Woźniak, M.; Gołembiowska, K.; Noworyta-Sokołowska, K.; Acher, F.; Cieślik, P.; Kusek, M.; Tokarski, K.; Pilc, A.; Wierońska, J.M. Neurochemical and behavioral studies on the 5-HT1A-dependent antipsychotic action of the mGlu4 receptor agonist LSP4-2022. Neuropharmacology 2017, 115, 149-165. [CrossRef]

15. Wierońska, J.M.; Sławińska, A.; Stachowicz, K.; Łasoń-Tyburkiewicz, M.; Gruca, P.; Papp, M.; Pilc, A. The reversal of cognitive, but not negative or positive symptoms of schizophrenia, by the mGlu2/3 receptor agonist, LY379268, is 5-HT1A dependent. Behav. Brain Res. 2013, 256, 298-304. [CrossRef] [PubMed]

16. Newman-Tancredi, A. Biased agonism at serotonin 5-HT $1 \mathrm{~A}$ receptors: Preferential postsynaptic activity for improved therapy of CNS disorders. Neuropsychiatry 2011, 1, 149-164. [CrossRef]

17. Celada, P.; Bortolozzi, A.; Artigas, F. Serotonin 5-HT1Areceptors as targets for agents to treat psychiatric disorders: Rationale and current status of research. CNS Drugs 2013, 27, 703-716. [CrossRef]

18. Ögren, S.O.; Eriksson, T.M.; Elvander-Tottie, E.; D’Addario, C.; Ekström, J.C.; Svenningsson, P.; Meister, B.; Kehr, J.; Stiedl, O. The role of 5-HT1A receptors in learning and memory. Behav. Brain Res. 2008, 195, 54-77. [CrossRef]

19. Newman-Tancredi, A.; Martel, J.C.; Assié, M.B.; Buritova, J.; Lauressergues, E.; Cosi, C.; Heusler, P.; Bruins Slot, L.; Colpaert, F.C.; Vacher, B.; et al. Signal transduction and functional selectivity of F15599, a preferential post-synaptic 5-HT 1A receptor agonist. Br. J. Pharmacol. 2009, 156, 338-353. [CrossRef]

20. Becker, G.; Bolbos, R.; Costes, N.; Redouté, J.; Newman-Tancredi, A.; Zimmer, L. Selective serotonin 5-HT1A receptor biased agonists elicit distinct brain activation patterns: A pharmacoMRI study. Sci. Rep. 2016, 6, 1-12. [CrossRef]

21. Cieślik, P.; Domin, H.; Chocyk, A.; Gruca, P.; Litwa, E.; Płoska, A.; Radulska, A.; Pelikant-Małecka, I.; Brański, P.; Kalinowski, L.; et al. Simultaneous activation of mGlu2 and muscarinic receptors reverses MK-801-induced cognitive decline in rodents. Neuropharmacology 2020, 174, 107866. [CrossRef]

22. Cieślik, P.; Woźniak, M.; Tokarski, K.; Kusek, M.; Pilc, A.; Płoska, A.; Radulska, A.; Pelikant-Małecka, I.; Żołnowska, B.; Sławiński, J.; et al. Simultaneous activation of muscarinic and GABA B receptors as a bidirectional target for novel antipsychotics. Behav. Brain Res. 2019, 359, 671-685. [CrossRef]

23. Cieślik, P.; Woźniak, M.; Rook, J.M.; Tantawy, M.N.; Conn, P.J.; Acher, F.; Tokarski, K.; Kusek, M.; Pilc, A.; Wierońska, J.M. Mutual activation of glutamatergic mGlu4 and muscarinic M4 receptors reverses schizophrenia-related changes in rodents. Psychopharmacology 2018, 235, 2897-2913. [CrossRef]

24. Cieślik, P.; Radulska, A.; Pelikant-Małecka, I.; Płoska, A.; Kalinowski, L.; Wierońska, J.M. Reversal of MK-801-Induced Disruptions in Social Interactions and Working Memory with Simultaneous Administration of LY487379 and VU152100 in Mice. Int. J. Mol. Sci. 2019, 20, 2781. [CrossRef]

25. Depoortère, R.; Auclair, A.L.; Bardin, L.; Colpaert, F.C.; Vacher, B.; Newman-Tancredi, A. F15599, a preferential post-synaptic 5-HT 1A receptor agonist: Activity in models of cognition in comparison with reference 5-HT 1A receptor agonists. Eur. Neuropsychopharmacol. 2010, 20, 641-654. [CrossRef]

26. Kraeuter, A.K.; Guest, P.C.; Sarnyai, Z. The Y-Maze for Assessment of Spatial Working and Reference Memory in Mice. In Methods in Molecular Biology; Humana Press: New York, NY, USA, 2019; Volume 1916, pp. 105-111; ISBN 9781493989942.

27. Antunes, M.; Biala, G. The novel object recognition memory: Neurobiology, test procedure, and its modifications. Cogn. Process. 2012, 13, 93-110. [CrossRef] [PubMed] 
28. Bevins, R.A.; Besheer, J. Object recognition in rats and mice: A one-trial non-matching-to-sample learning task to study "recognition memory". Nat. Protoc. 2006, 1, 1306-1311. [CrossRef] [PubMed]

29. Dalley, J.W.; Cardinal, R.N.; Robbins, T.W. Prefrontal executive and cognitive functions in rodents: Neural and neurochemical substrates. Neurosci. Biobehav. Rev. 2004, 28, 771-784. [CrossRef]

30. Frith, C.; Dolan, R. The role of the prefrontal cortex in higher cognitive functions. Cogn. Brain Res. 1996, 5, 175-181. [CrossRef]

31. Levey, A.I.; Kitt, C.A.; Simonds, W.F.; Price, D.L.; Brann, M.R. Identification and localization of muscarinic acetylcholine receptor proteins in brain with subtype-specific antibodies. J. Neurosci. Off. J. Soc. Neurosci. 1991, 11, 3218-3226. [CrossRef]

32. Levey, A.I. Immunological localization of m1-m5 muscarinic acetylcholine receptors in peripheral tissues and brain. Life Sci. 1993, 52, 441-448. [CrossRef]

33. Brady, A.E.; Jones, C.K.; Bridges, T.M.; Kennedy, J.P.; Thompson, A.D.; Heiman, J.U.; Breininger, M.L.; Gentry, P.R.; Yin, H.; Jadhav, S.B.; et al. Centrally Active Allosteric Potentiators of the M4 Muscarinic Acetylcholine Receptor Reverse AmphetamineInduced Hyperlocomotor Activity in Rats. J. Pharmacol. Exp. Ther. 2008, 327, 941-953. [CrossRef]

34. Bridges, T.M.; Marlo, J.M.; Niswender, C.M.; Jones, C.K.; Jadhav, S.B.; Gentry, P.R.; Plumley, H.C.; Weaver, C.D.; Conn, P.J.; Lindsley, C.W. Discovery of the First Highly M5-Preferring Muscarinic Acetylcholine Receptor Ligand, an M5 Positive Allosteric Modulator Derived from a Series of 5-Trifluoromethoxy N-Benzyl Isatins. J. Med. Chem. 2009, 52, 3445-3448. [CrossRef]

35. Lebois, E.P.; Bridges, T.M.; Lewis, L.M.; Dawson, E.S.; Kane, A.S.; Xiang, Z.; Jadhav, S.B.; Yin, H.; Kennedy, J.P.; Meiler, J.; et al. Discovery and characterization of novel subtype-selective allosteric agonists for the investigation of M1 receptor function in the central nervous system. ACS Chem. Neurosci. 2010, 1, 104-121. [CrossRef]

36. Shekhar, A.; Potter, W.Z.; Lightfoot, J.; Lienemann, J.; Dubé, S.; Mallinckrodt, C.; Bymaster, F.P.; McKinzie, D.L.; Felder, C.C. Selective muscarinic receptor agonist xanomeline as a novel treatment approach for schizophrenia. Am. J. Psychiatry 2008, 165, 1033-1039. [CrossRef]

37. Yohn, S.E.; Conn, P.J. Positive allosteric modulation of M1 and M4 muscarinic receptors as potential therapeutic treatments for schizophrenia. Neuropharmacology 2018, 136, 438-448. [CrossRef]

38. Langmead, C.J.; Watson, J.; Reavill, C. Muscarinic acetylcholine receptors as CNS drug targets. Pharmacol. Ther. 2008, 117, $232-243$. [CrossRef]

39. Cieślik, P.; Wierońska, J.M. Regulation of glutamatergic activity via bidirectional activation of two select receptors as a novel approach in antipsychotic drug discovery. Int. J. Mol. Sci. 2020, 21, 8811. [CrossRef]

40. Carlsson, M.; Carlsson, A. Schizophrenia: A Subcortical Neurotransmitter Imbalance Syndrome? Schizophr. Bull. 1990, 16, 425-432. [CrossRef]

41. Moghaddam, B.; Adams, B.; Verma, A.; Daly, D. Activation of glutamatergic neurotransmission by ketamine: A novel step in the pathway from NMDA receptor blockade to dopaminergic and cognitive disruptions associated with the prefrontal cortex. J. Neurosci. 1997, 17, 2921-2927. [CrossRef]

42. Olney, J.W.; Farber, N.B. Glutamate receptor dysfunction and schizophrenia. Arch. Gen. Psychiatry 1995, 52, 998-1007. [CrossRef]

43. Conn, P.J.; Lindsley, C.W.; Jones, C.K. Activation of metabotropic glutamate receptors as a novel approach for the treatment of schizophrenia. Trends Pharmacol. Sci. 2009, 30, 25-31. [CrossRef] [PubMed]

44. Moghaddam, B. Targeting metabotropic glutamate receptors for treatment of the cognitive symptoms of schizophrenia. Psychopharmacology 2004, 174, 39-44. [CrossRef]

45. Javitt, D.C.; Zukin, S.R. Recent Advances in the Phencyclidine Model of Schizophrenia. Am. J. Psychiatry 1991, 148, 1301-1308.

46. Carlsson, A. Does dopamine play a role in schizophrenia? Psychol. Med. 1977, 7, 583-597. [CrossRef]

47. Jastrzębska-Więsek, M.; Partyka, A.; Rychtyk, J.; Śniecikowska, J.; Kołaczkowski, M.; Wesołowska, A.; Varney, M.A.; Newman-Tancredi, A. Activity of Serotonin 5-HT1A Receptor Biased Agonists in Rat: Anxiolytic and Antidepressant-like properties. ACS Chem. Neurosci. 2018, 93, 52-67. [CrossRef]

48. Assié, M.B.; Bardin, L.; Auclair, A.L.; Carilla-Durand, E.; Depoortère, R.; Koek, W.; Kleven, M.S.; Colpaert, F.; Vacher, B.; Newman-Tancredi, A. F15599, a highly selective post-synaptic 5-HT1A receptor agonist: In-vivo profile in behavioural models of antidepressant and serotonergic activity. Int. J. Neuropsychopharmacol. 2010, 13, 1285-1298. [CrossRef] [PubMed]

49. Miedel, C.J.; Patton, J.M.; Miedel, A.N.; Miedel, E.S.; Levenson, J.M. Assessment of Spontaneous Alternation, Novel Object Recognition and Limb Clasping in Transgenic Mouse Models of Amyloid- $\beta$ and Tau Neuropathology. J. Vis. Exp. 2017, 123, 55523. [CrossRef] 